\title{
Série de
}

\section{TRABALHOS}

PARA DISCUSSÃO

Working Paper Series

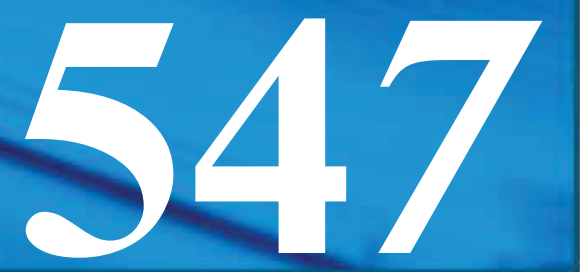

APRIL 2021

Financial Access and Labor Market Outcomes: evidence from credit lotteries

Bernardus Van Doornik, Armando Gomes, David Schoenherr, Janis Skrastins 
ISSN 1518-3548 CGC 00.038.166/0001-05

p. $1-45$ 


\section{Working Paper Series}

Edited by the Research Department (Depep) - E-mail: workingpaper@bcb.gov.br

Editor: Rodrigo Barbone Gonzalez

Co-editor: José Valentim Machado Vicente

Head of the Research Department: André Minella

Deputy Governor for Economic Policy: Fabio Kanczuk

The Banco Central do Brasil Working Papers are evaluated in double-blind referee process.

Although the Working Papers often represent preliminary work, citation of source is required when used or reproduced.

The views expressed in this Working Paper are those of the authors and do not necessarily reflect those of the Banco Central do Brasil.

As opiniões expressas neste trabalho são exclusivamente do(s) autor(es) e não refletem, necessariamente, a visão do Banco Central do Brasil.

\section{Citizen Service Division}

Banco Central do Brasil

Deati/Diate

SBS - Quadra 3 - Bloco B - Edifício-Sede - $2^{\circ}$ subsolo

70074-900 Brasília - DF - Brazil

Toll Free: 08009792345

Fax: +55 (61) 3414-2553

Internet: http//www.bcb.gov.br/?CONTACTUS 


\section{Non-Technical Summary}

Various interventions have been proposed to overcome hurdles to economic development for low-income households. Much hope has been placed in the transformative power of financial access: the marginal return on capital should be largest for the most capital-constrained individuals. Yet, randomized-control trials across a diverse set of settings and countries document modest or no effects of extending credit to low-income households. These findings raise the question of whether the return on capital is generally lower than expected for credit-constrained households or whether interventions require better targeting of populations and investments that generate higher returns.

We contribute to this question by documenting that facilitating access to credit for investment in mobility yields high and persistent returns. We exploit data on participants in a group-lending mechanism - Consorcios in Brazil, which generates random time-series variation in access to credit tied to the purchase of a motorcycle. Consorcios are a wide spread grouplending mechanism to finance durable goods in Brazil with more than $6.7 \mathrm{~m}$ participants in a given year. We focus on motorcycle groups, which tend to comprise credit-constrained individuals seeking to invest in individual mobility.

We find large and persistent increases in formal employment and labor income after individuals obtain access to credit. Specifically, formal employment rates increase by 2 percentage points and salaries are 18 percent higher ten years after obtaining credit. Access to credit for investment in mobility yields an annual rate of return of 16.94 percent over a period of 10 years. Consistent with the ability to engage in a geographically broader job search, we find that individuals transition to jobs further away from home or public transportation. The effects are larger for lower-income individuals and in areas with less developed public transportation and sparse local labor markets.

Altogether, these findings show that extending credit for investment in mobility enables individuals to access geographically distant labor markets, generating large income effects. An important rationale underlying the targeting of capital at entrepreneurs is that labor markets are often assumed to be fully accessible to capital-constrained individuals, since they do not require upfront investment. Our findings suggest that this may not be the case. 


\section{Sumário Não Técnico}

Várias intervenções têm sido propostas para superar os obstáculos ao desenvolvimento econômico das famílias de baixa renda. Muita esperança tem sido colocada no poder transformador do acesso financeiro: o retorno marginal sobre o capital deveria ser maior para os indivíduos com maiores restrições de capital. No entanto, testes de controle aleatórios realizados em um conjunto diversificado de cenários e países demonstram efeitos modestos ou nulos da extensão do crédito para as famílias de baixa renda. Esses resultados levantam a dúvida: é o retorno sobre o capital que geralmente é menor do que o esperado para as famílias com restrições de crédito ou são as intervenções que precisam ser direcionadas a populações e investimentos que gerem maiores retornos?

Contribuímos para essa questão ao verificar que a facilitação do acesso ao crédito para investimento em mobilidade produz retornos altos e persistentes. Utilizamos dados sobre os participantes de um mecanismo de empréstimo em grupo - Consórcios - no Brasil, que geraram uma variação temporal aleatória no acesso ao crédito vinculado à compra de motocicletas. Consórcios são mecanismos abrangentes de financiamento de bens duráveis no Brasil, com mais de 6,7 milhões de participantes por ano. Focamos em grupos de consórcio de motocicletas, que normalmente incluem indivíduos com restrições de crédito interessados em investir em sua mobilidade individual.

Foram verificados aumentos abrangentes e persistentes no emprego formal e na renda depois que os indivíduos obtiveram acesso ao crédito. Especificamente, as taxas de emprego formal aumentaram em 2 pontos percentuais e os salários cresceram $18 \%$ nos dez anos seguintes à obtenção de crédito. O acesso ao crédito para investimento em mobilidade produziu uma taxa de retorno anual de 16,94\% durante um período de 10 anos. Consistente com a capacidade de buscar emprego em região geograficamente mais ampla, descobrimos que os indivíduos transitam para empregos mais longe de casa, independentemente do transporte público. Os efeitos são ainda maiores para indivíduos de baixa renda e em áreas com transporte público menos desenvolvido e com mercados de trabalho locais mais escassos.

No conjunto, essas descobertas mostram que a extensão do crédito para investimento em mobilidade permite que os indivíduos tenham acesso a mercados de trabalho geograficamente distantes, gerando grandes efeitos sobre a renda. Um importante raciocínio subjacente ao direcionamento do capital para os empreendedores é que os mercados de trabalho são frequentemente considerados como sendo totalmente acessíveis a indivíduos com limitações de capital, uma vez que não requerem investimento inicial. Nossas conclusões sugerem que esse pode não ser o caso. 


\title{
Financial Access and Labor Market Outcomes: Evidence from Credit Lotteries ${ }^{*}$
}

\author{
Bernardus Van Doornik ${ }^{* *}$ \\ Armando Gomes ${ }^{* * *}$ \\ David Schoenherr ${ }^{* * * *}$ \\ Janis Skrastins ${ }^{* * * *}$
}

\begin{abstract}
We assess the employment and income effects of access to credit dedicated to investment in individual mobility (a motorcycle). For identification, we exploit random time-series variation in access to credit through random lotteries for participants in a group-lending mechanism in Brazil. We find that access to credit for investment in individual mobility permanently increases formal employment rates and salaries, yielding an annual real rate of return of 16.94 percent over a ten-year horizon. Consistent with a geographically broader job search, we find that individuals transition to jobs further away from home and public transportation. Our results suggest that credit constraints prevent individuals from accessing parts of the labor market. As a consequence, extending credit for investment in mobility enables individuals to access geographically distant labor market opportunities, yielding high and persistent returns.
\end{abstract}

JEL Codes: D14, G23, J62, R20, R23.

Keywords: access to credit, household finance, labor mobility, spatial mismatch.

The Working Papers should not be reported as representing the views of the Banco Central do Brasil. The views expressed in the papers are those of the authors and do not necessarily reflect those of the Banco Central do Brasil.

\footnotetext{
${ }^{*}$ We thank Heitor Almeida, Deniz Aydin, Leah Boustan, Jonathan Cohn, Phil Dybvig, Maryam Farboodi, Dimas Fazio, Thomas Fujiwara, Radha Gopalan, Gregor Jarosch, Marcio Kuroski, Mina Lee, Jose Liberti, Alexandre Mas, Adrien Matray, Ben Moll, Larry Schmidt, Jinfei Sheng, Sascha Steffen, Maria Micaela Sviatschi, Margarita Tsoutsoura, and seminar participants at the Banco Central do Brasil, FGV Rio, MIT, Princeton University, SSE Riga, University of Pittsburgh, Stanford GSB, Vanderbilt University, Washington University in St. Louis, Yale University, and York University, and conference participants at the Cambridge Alternative Finance Conference, the AEA, the Northeastern Finance Conference, the Labor and Finance Conference, the SFS Winter Conference, the 29th European Summer Symposium in Financial Markets (Gerzensee), the 2018 UBC Winter Finance Conference, IFWSAS, the CEPR European Conference on Household Finance, and the International Conference on Banking and Economic Development (FGV Rio) for their many helpful comments and suggestions.

${ }^{* *}$ Banco Central do Brasil, bernardus.doornik@bcb.gov.br

${ }^{* * *}$ Washington University in St. Louis, gomes@wustl.edu

**** Princeton University, schoenherr@princeton.edu

**** Washington University in St. Louis, jskrastins@wustl.edu
} 


\section{Introduction}

Various interventions have been proposed to overcome hurdles to economic development for low-income households. Much hope has been placed in the transformative power of financial access: the marginal return on capital should be largest for the most capital-constrained individuals. Yet, randomized-control trials across a diverse set of settings and countries document modest or no effects of extending credit to low-income households (Banerjee et al., 2015; Crepon et al., 2015; Angelucci, Karlan, and Zinman, 2015; Attanasio et al., 2015; Augsburg et al., 2015). These findings raise the question of whether the return on capital is generally lower than expected for credit-constrained households or whether interventions require better targeting of populations and investments that generate higher returns. ${ }^{1}$

We contribute to this question by documenting that facilitating access to credit for investment in mobility yields high and persistent returns. We exploit data on participants in a group-lending mechanism in Brazil, which generates random timeseries variation in access to credit tied to the purchase of a motorcycle. We find large and persistent increases in formal employment and labor income after individuals obtain access to credit. Specifically, formal employment rates increase by 2 percentage points and salaries are 18 percent higher ten years after obtaining credit. Access to credit for investment in mobility yields an annual rate of return of 16.94 percent over a period of 10 years. Consistent with the ability to engage in a geographically broader job search, we find that individuals transition to jobs further away from home or public transportation. The effects are larger for lower-income individuals and in areas with less developed public transportation and sparse local labor markets.

Altogether, these findings show that extending credit for investment in mobility enables individuals to access geographically distant labor markets, generating large income effects. An important rationale underlying the targeting of capital at entrepreneurs is that labor markets are often assumed to be fully accessible to capital-constrained individuals, since they do not require upfront investment (e.g. Banerjee and Newman 1993). Our findings suggest that this may not be the case. This insight is supported by recent evidence in Banerjee, Duflo, and Sharma (2020) that positive long-term effects on labor income from a cash grant program in West

\footnotetext{
${ }^{1}$ For example, Banerjee et al. (2019) find positive effects of easier access to credit for experienced but not new entrepreneurs and Hussam, Rigol, and Roth (2020) show that eliciting community information may help identify highly skilled entrepreneurs. Karlan and Zinman (2011) find that returns on investment are larger for higher-income male entrepreneurs. Beaman et al. (2020) document that cash grants only yield positive returns to individuals who actively select into credit markets.
} 
Bengal are linked to migration to more distant urban centers.

Consorcios are a wide spread group-lending mechanism to finance durable goods in Brazil with more than $6.7 \mathrm{~m}$ participants in a given year. We focus on motorcycle groups, which tend to comprise credit-constrained individuals seeking to invest in individual mobility. ${ }^{2}$ Every month, participants in a consorcio group make identical contributions, which are then allocated to a subset of participants as credit designated for motorcycle purchase. Recipients of credit are determined through lotteries and auctions. When allocating credit through lotteries, consorcios use a contractually specified algorithm to translate the outcome of the national lottery (Loteria Federal) into ticket numbers that have been assigned to all participants beforehand. ${ }^{3}$ All participants continue their contributions until everybody has been awarded credit. In many ways, consorcios resemble rotating savings and credit associations (ROSCAs) (Besley, Coate, and Loury, 1993; Besley and Coate, 1995). One main difference is that enforcement operates through physical collateral rather than social capital. Participants share no social ties and do not live in geographic proximity.

Identifying a causal effect of access to credit for investment in mobility on income is challenging. Access to credit results from endogenous decisions, which depend on characteristics that may be correlated with other economic variables. For example, unobservable characteristics such as skills may jointly determine access to credit and labor market outcomes.

To overcome these challenges, we exploit random time-series variation in access to credit provided by consorcio groups. Specifically, we employ a staggered differencein-differences (DID) methodology in which we compare outcomes for participants who receive credit through a lottery with participants who have not yet received credit within the same group (group-time fixed effects). This design controls for selection by and into a particular group. Since variation in the timing of access to credit depends on the outcomes of random lotteries, access to credit is orthogonal to other characteristics. Moreover, the fact that participants in a consorcio group do not share social ties and do not live in geographic proximity mitigates concerns about multiplier or other general equilibrium effects that may differentially affect treated and untreated individuals (Cai and Szeidl, 2019; Breza and Kinnan, 2020).

Most groups allocate credit through lotteries and auctions. Participation in auc-

\footnotetext{
${ }^{2}$ One-third of motorcycles in Brazil are sold through consorcios (ABAC, 2017). From 2009 to 2016, more than 10 million individuals (6.6 percent of working-age population) participated in a motorcycle consorcio.

${ }^{3}$ This ensures that lotteries are transparent and fair. The algorithm is designed such that ex ante each participant has the same probability of winning the lottery in a given month (see Section 2.2 for details).
} 
tions could be related to other economic variables, such as labor market opportunities. To resolve potential endogeneity concerns related to auctions, we implement an instrumental variable strategy. ${ }^{4}$ The contractual design of consorcios, combined with our data, allow us to simulate all groups as if credit were allocated only through lotteries. Specifically, since we know the algorithm that a group employs to translate the national lottery number into the winning ticket number, we can identify who would have obtained credit through a lottery if the group held no auctions. We use these simulated lottery winners as an instrument to predict the actual lottery winners (see Section 4.3 for details). Since the instrument is based on the outcomes of random lotteries, it is orthogonal to other characteristics and satisfies the exclusion restriction.

We first assess how access to credit for investment in mobility affects formal employment and salaries. Administrative data on all formal employment contracts in Brazil allows us to observe outcomes for up to 10 years after receiving credit. We find an increase in formal employment rates by 2 percentage points (4 percent) in the first year after obtaining credit, which persists over 10 years after obtaining credit. In terms of salaries, we find a 5 percent increase in the first year after receiving credit relative to participants who did not receive credit. This difference increases to 18 percent 10 years after receiving credit. Over 10 years, the aggregate extra salary from access to credit for investment in mobility amounts to 70 percent of an annual pre-treatment salary.

Our data allows us to compute two metrics to capture commuting patterns: the distance between where an individual works and where they live, and the distance between where an individual works and the nearest bus stop. For both metrics, we observe an increase of about 5 percent in the first year after obtaining credit, which rises to 14-20 percent 10 years after obtaining credit. These patterns suggest that access to credit for investment in mobility enables individuals to engage in a geographically broader job search. Examining how much salary increases for an individual depending on the change in commuting distance after obtaining a motorcycle, we estimate an elasticity of salary with respect to the distance between an individual's workplace and their home or the nearest bus stop of 0.05 and 0.03 , respectively. An additional channel through which individuals may generate income from the motorcycle is as a production factor, for example as a delivery rider. However, this type of activity is mostly confined to the informal sector, preventing us from observing it in the data.

\footnotetext{
${ }^{4}$ One may be tempted to solve endogeneity problems of auctions by restricting the sample to lottery winners. However, the endogenous decision to participate in auctions affects the composition of the pool of remaining participants. This in turn could lead to different types of estimation bias.
} 
In the cross-section, we observe heterogeneous treatment effects that vary with individual- and location-specific characteristics. Individuals who live in areas with less developed public transportation and fewer local employment opportunities, and younger individuals with lower salaries experience a greater increase in employment, salaries, and commuting distance. These findings suggest that investment in individual mobility can be a substitute for public transportation, and that returns to credit for investment in mobility are higher for young, low-income individuals who live in areas with sparse local labor markets.

The design of consorcios allows us to examine whether the timing of access to credit for investment in mobility matters. While participants in a given consorcio group select into the contract at the same time, the timing of when they obtain credit varies by up to five years. We find that the treatment effect is independent of the timing of access to credit. That is, both pre-treatment and post-treatment trends look the same for individuals who obtain credit earlier or obtain credit later. ${ }^{5}$ This suggests that the decision to seek access to credit through a consorcio is not driven by time-sensitive labor market opportunities. Instead, credit constraints that prevent individuals from investment in mobility restrict their labor market access persistently. Access to credit allows them to permanently increase their labor income, similar to the idea of a poverty trap that requires a sizable initial investment to put individuals onto a positive growth trajectory (Dasgupta and Ray, 1986; Banerjee and Newman, 1993; Galor and Zeira, 1993).

We complement our analysis with additional tests to tighten the interpretation of the results. Participating in a consorcio group may affect individuals' labor market outcomes even before they obtain credit. We provide evidence that this is not the case. We find no different pre-treatment trends in labor market outcomes or commuting patterns for early and late recipients of credit. In addition, we show that all outcomes are insensitive to variation in the expected timing of access to credit (see Section 7.2 for details). Furthermore, our results are virtually identical for municipalities with below- and above-median levels of labor market informality, suggesting that the results are not primarily driven by changes between informal and formal employment.

Our paper relates to an active debate on returns to facilitating access to capital for capital-constrained individuals. While much hope has been placed in a transformative impact of financial access, a number of recent studies suggests that returns are modest at best (Karlan and Zinman, 2011; Attanasio et al., 2015; Augsburg et al., 2015; Banerjee et al., 2015; Crepon et al., 2015; Tarozzi, Desai, and Johnson,

\footnotetext{
${ }^{5}$ Nonetheless, obtaining access to credit for investing in mobility earlier increases aggregate labor income by initiating the positive employment and salary effects earlier.
} 
2015; Meager, 2019; Gertler, Green, and Wolfram, 2021). ${ }^{6}$ Recent evidence suggests that while the return on access to capital is low on average, it may be high for specific groups. For example, Banerjee et al. (2019) and Meager (2020) find positive effects of easier access to credit only for entrepreneurs with entrepreneurial experience, which suggests that credit expansion may be more productive at the intensive rather than at the extensive margin. Karlan and Zinman (2011) find that returns on investment are larger for higher-income male entrepreneurs, who are less likely to be targeted by current interventions.

The results in our paper contribute to this debate by showing that access to credit tied to investment in mobility can yield high and persistent returns. Many existing programs and RCTs extend credit or cash grants to entrepreneurs, based on the insight that credit is essential for starting a new business, which requires a large upfront investment. In contrast, participation in labor markets is typically assumed not to require an upfront investment. Our results question this assumption by showing that individuals may not be able to freely participate in labor markets due to constraints in spatial mobility. Overcoming these may require a large upfront investment and therefore access to credit. This insight is consistent with recent evidence in Banerjee, Duflo, and Sharma (2020) that persistent long-term effects on labor income from a cash grant program in West Bengal are tied to migration to more distant urban centers. Studies that report which type of investment individuals undertake after credit constraints are relaxed repeatedly identify investment in mobility as one of the highest priorities (Karlan and Zinman, 2010; Kaboski and Townsend, 2012).

Participants in motorcycle consorcios are individuals who self-select into credit for investment in mobility. This matters. In a recent study, Beaman et al. (2020) document that cash grants only yield positive returns to individuals who have previously sought access to credit. This suggests that targeting a population that actively seeks access to capital is important. Typically, endogeneity problems prevent researchers from drawing firm conclusions from non-experimental variation in access to credit, since selection into loan contracts is likely to be endogenously related to other economic variables. In this respect, consorcios are unique as an institutional setting since all participants select into the credit product, and variation in the timing of access to credit is determined through random lotteries. Since this variation is conditional on selection into the contract, it is not subject to concerns about confounding

\footnotetext{
${ }^{6}$ Limited access to credit is not a phenomenon exclusive to mid- or low-income countries. The evidence in developed countries is also mixed. While some studies find positive effects of extending credit to low-income households across different measures (Zinman, 2010; Morse, 2011; Morgan, Strain, and Seblani, 2012), a large set of studies document negative effects (Melzer, 2011; Campbell, Martinez-Jerez, and Tufano, 2012; Carrell and Zinman, 2014; Skiba and Tobacman, 2019).
} 
factors correlated with seeking access to credit. This allows us to provide evidence on the effects of access to credit for a population that selects into the credit market in a non-experimental setting.

Our results also relate to the literature on mobility and labor markets more broadly. The idea of spatial mismatch between where individuals live and job opportunities has been around for a while in the urban economics literature (Kain 1968; Ihlanfeldt and Sjoquist 1998). While theoretically plausible, establishing the prevalence of spatial mismatch in the data is challenging. Individuals and firms may optimize their location such that spatial mismatch is not a first-order concern. For example, Marinescu and Rathelot (2018) argue that spatial mismatch explains only 5.3 percent of U.S. unemployment, as job seekers live close to potential vacancies. Consistent with the findings in Marinescu and Rathelot (2018), we find that extensive margin effects (employment rates) are relatively small. However, intensive margin effects (quality of employment) are large. Individuals with access to individual mobility earn 18 percent higher salaries in the long run, amounting to 0.7 annual salaries over a ten-year period. ${ }^{7}$

\section{Consorcios}

This section provides a detailed description of consorcio groups and the way they allocate credit designated for the purchase of durable goods.

\subsection{Basic Features}

Consorcios are a financial product in which participants pool funds to save towards the purchase of durable goods. Consorcio groups are typically administered by the finance division of a manufacturer who provides the good, a bank, or a specialty finance company. The administrator is in charge of marketing the consorcio, selecting participants, managing payments, and enforcing contracts. The administrator is compensated for these services through an administrative fee levied on all participants. Screening of applicants is virtually non-existent and it is easy for anyone with a social security number in Brazil to sign up and participate.

Prospective participants are provided with several pieces of information when selecting a group. They know the identity of the administrator, the price of the good, the number of months for which the group will operate, and the target number

\footnotetext{
${ }^{7}$ Similarly, Bryan, Chowdhury, and Mobarak (2014) document positive consumption effects from cash grants for migration.
} 
of participants. All participants contribute identical pre-determined payments at regular intervals, typically monthly. These payments are adjusted for inflation. The monthly payments also cover the administrative fee and establish a guarantee fund that covers losses from defaults of individual participants. ${ }^{8}$ All participants are required to continue their monthly contributions, including those who have received credit from the group. The group continues until all participants have received credit.

Due to the organization of the group through a central and independent administrator, personal connections between consorcio participants are uncommon and participants in the same group are not known to each other. Enforcement relies on physical collateral generated by the durable good purchased through the group.

\subsection{Credit Allocation}

All participants start out as savers making equal contributions to the group. Every month some participants receive credit from the group. Which members receive credit in a given month is decided using two mechanisms: lotteries and auctions. The relative numbers of lotteries and auctions vary by group. By law, at least one good has to be allocated through a lottery each period.

Lotteries are based on the national lottery in Brazil (Loteria Federal), which is broadcast on TV. Each participant receives a ticket number at the start of the group. Based on an algorithm, which is contractually specific, the national lottery number is translated into a ticket number and the participant holding the respective ticket number is declared the winner of the lottery. Each algorithm is designed such that at the beginning of the group each participant has the same unconditional probability of winning the lottery at any point in time. A detailed description of an algorithm is provided in Appendix A.1.

In credit auctions, participants bid a fraction of the total value of the good. Rather than a higher aggregate payment, bids move payments forward, akin to making a higher down payment on the loan given by the group. Future contributions are adjusted accordingly. For example, if the value of a good is $\$ 5,000$ with monthly contributions of $\$ 100$ and a participant bids 40 percent, they would pay $\$ 2,000$ immediately and would cease making monthly payments 20 months before the end of the group.

\footnotetext{
${ }^{8}$ In most groups a fraction of the payments is used to insure the good against damage to preserve its value as collateral.
} 


\subsection{Defaults}

After obtaining credit from either a lottery or an auction, the good is purchased and becomes the property of the group. The good serves as physical collateral and can be seized if payments are late. ${ }^{9}$ Participants cannot sell the good to somebody else without the approval of the administrator to ensure that the good is not transferred to somebody who is a high credit risk to the group.

If a participant defaults before receiving credit, their past payments are retained by the group until they win a lottery. Once they win a lottery, their funds are released instead of credit being allocated. However, defaulted participants receive only a fraction of their previous payments since default carries a contractually specified penalty of, on average, about 35 percent of the payments for motorcycle groups. ${ }^{10}$

Due to this contractual design, defaults of participants before receiving credit do not affect the required payments of other participants. However, defaults after receiving credit impose costs on the group if the collateral value of the good is not sufficient to recover the full amount of credit that is owed to the group. The resulting losses are first covered by the guarantee fund, which is designed to be sufficiently generous to make a collapse of the group highly unlikely. If losses exceed the capacity of the guarantee fund, administrators usually absorb the losses. In practice, losses from defaults virtually never exceed the capacity of the guarantee fund. At the termination date of the group, any remaining funds in the reserve fund are split equally and repaid to the participants.

\section{$2.4 \quad$ Aggregate Statistics}

Consorcios are widespread in Brazil. In 2015, consorcios had 6,705,673 participants, and about half of them were in motorcycle consorcios. The 3,407,678 motorcycle consorcio participants are equivalent to 2.25 percent of the working age population or 6.82 percent of formally employed individuals in Brazil. 444,636 individuals, or 0.29 percent of the working-age population obtained a motorcycle through a consorcio group in 2015 alone.

The average motorcycle value across all groups is USD 2,837. Average monthly payments amount to about 3 percent of the value of the motorcycle. These payments cover the costs of the motorcycle, an average administrative fee of 16.84 percent of

\footnotetext{
${ }^{9}$ Consorcios register all real estate and vehicle collateral under the fiduciary lien (Alienação fiduciária) which allows for out of court settlement in the event of default. As a consequence, collateral can be recovered quickly upon default.

${ }^{10}$ In groups started before 2009, participants who defaulted before receiving credit had to wait until the end of the group to have their payments returned.
} 
the value of the motorcycle, and a guarantee fund to cover losses. The average duration of a consorcio group is 48.4 months. The share of motorcycles allocated through lotteries is 36.71 percent with the rest allocated through auctions. Consistent with consorcio groups not relying on social ties among participants, the average group comprises 284 participants from 153 different municipalities in 17 different states (out of 27). Thus, fewer than two participants in the same group are from a given municipality.

Not all participants eventually obtain a motorcycle. 23.25 percent of participants exit the group before they obtain credit due to missed payments. ${ }^{11}$ Participants who exit before obtaining a motorcycle have their payments returned after a deduction of an average penalty of 22.17 percent. As described above, these funds are not returned immediately. For groups started before 2009, the funds were returned at the end of the group. For groups stated in 2009 or later, participants have their funds returned when they are drawn in a lottery. An additional 15.08 percent of participants default after receiving credit, in which case the motorcycle may be seized by the group to cover outstanding payments. If the liquidation value of the motorcycle is higher than the outstanding payments, the non-defaulted participants keep the difference.

\section{Data}

The data for this paper comes from two main sources. Data on consorcios is from the Sistema de Administracao de Grupos/Cotas de Consorcio (SAG) database, which is maintained by the Banco Central do Brasil (BCB). Information on labor market outcomes is available through RAIS (Relacao Anual de Informacoes Sociais), an employer-employee matched database that includes employment information and wages for all formally employed workers in Brazil.

The database on consorcios provides information on the administrator, all participants, the good that is being allocated, and the dates when credit is awarded to participants. The BCB has been collecting data on all consorcio groups since October 15, 2008, including consorcios that started earlier, but were still ongoing. The earliest starting date of a consorcio group in our sample is January 2006 and the sample ends in December 2015. For our empirical analysis, information about the algorithms through which consorcio groups translate the national lottery draw into a number that matches the ticket number of a participant is required. This

\footnotetext{
${ }^{11}$ In addition, some individuals sign up but change their mind before making payments, in which case they are excluded from the group.
} 
information is not readily available in the database. We hand-collect data from as many administrators as possible and verify the algorithms in the data.

The consorcio database provides the social security number of all participants. This allows us to match them to the RAIS database. The RAIS database records information on all formally employed workers and is maintained by the Ministry of Economics. All formally registered firms in Brazil are legally required to report annual information on each worker that the firm employs. RAIS includes detailed information on the employer (tax number, sector of activity, establishment size, geographical location), the employee (social security number, age, gender, education), and the employment relationship (salary, tenure, type of employment, hiring date, layoff date, reason for layoff, etc.). Consistent with the sample period for consorcios, we use data from RAIS for the period from 2002 to 2015. By the end of 2015, the database covers about 50 million formal employees.

The final sample for our analysis comprises all groups for which we can collect the algorithm used to translate the national lottery number into a number matching the ticket number of a participant. We are able to identify the algorithm for 8,893 groups. Our sample comprises all lottery winners based on simulated allocations that treat every consorcio group as if all credit were allocated through lotteries (see Section 4.3 for details). Since the sample selection is determined by random lottery draws, it is in itself random.

Table 1 provides descriptive statistics for our sample. Panel A provides descriptive statistics for consorcio groups and Panel B for participants. The data contains 8,893 consorcio groups that allocate motorcycles through auctions and random lotteries between 2006 and 2015. The random sample of members of these groups who are predicted to win a lottery based on the algorithm used by the group's administrator leaves us with an average group size of 30.26 participants, with a median of 24 participants. Thus, the total number of participants our sample is 269,056.

The average monthly salary across all participants in motorcycle consorcios is BRL 1494. This compares to an average salary of BRL 1784 in the working-age population. The average consorcio participant is similar to the average person in the population along many characteristics, such as the propensity to own a business or the industries they are employed in. Notable differences include gender, with consorcio participants being about twenty percentage points more likely to be male, and education, with consorcio participants being less likely to have graduated from university than the general population.

Our distance measures are created using several data sources. We do not have information on the addresses of individuals and firms, but on their ZIP codes. ZIP 
code information comes from the RAIS establishment data for firms and the IRS population registry for individuals. ZIP code information is available for about a third of individuals and for half of firms in our sample. The latitude and longitude coordinates for ZIP codes are from the GeoPostcodes geographic database. Using these coordinates, we compute the actual travel distance (not air-line distance) between the center of the ZIP code in which an individual lives and the center of the ZIP code of their workplace, and between the center of the ZIP code of their workplace and the closest bus stop using Google Map's geocoding services.

In the population registry we observe the most recent snapshot (i.e., the information about an individual's home as of 2015). This introduces measurement error in our distance measures and prevents us from examining whether access to individual mobility affects where individuals choose to live. As a consequence, we cap commuting distances at 100 kilometers, as commuting distances above $100 \mathrm{~km}$ are likely due to data errors (for example, individuals may report their parents' address after moving or may have lived at a different address before 2015). The average commuting distance before gaining access to a motorcycle is 10.84 kilometers, and the median commuting distance is $5.95 \mathrm{~km}$.

\section{Empirical Strategy}

This section outlines our estimation strategy to assess the effect of access to credit for investment in individual mobility on employment rates and salaries, exploiting credit allocation in motorcycle consorcios.

\subsection{Endogeneity Problem}

Estimating the effect of access to credit for investment in individual mobility on various outcomes implies the following regression equation

$$
Y_{i t}=\alpha_{i}+\alpha_{t}+\beta \cdot C_{i t}+\delta \cdot \eta_{i t}+\epsilon_{i t}
$$

where $Y_{i t}$ is the outcome of interest, individual fixed effects $\alpha_{i}$ ensure that outcomes are tracked for the same individual, time fixed effects $\alpha_{t}$ control for time-series changes in outcomes common to all individuals, and $\eta_{i t}$ denotes time-varying characteristics that affect individuals' outcomes. The coefficient $\beta$ measures the effect of access to credit $C_{i t}$ on the outcome.

The fundamental problem in assessing the effect of individual mobility on labor market outcomes is that access to credit for investment in mobility $\left(C_{i t}\right)$ is 
endogenous and depends on characteristics that may be correlated with unobserved economic variables that also affect the outcome $\left(\eta_{i t}\right)$. In this case, $\operatorname{corr}\left(C_{i t}, \eta_{i t}\right) \neq 0$ and the estimate $\widehat{\beta}$ is biased.

\subsection{Consorcios}

We exploit consorcio groups to obtain exogenous time-series variation in access to credit for investment in individual mobility. In the context of consorcio groups, equation (1) translates to

$$
Y_{i t}=\alpha_{i}+\alpha_{g t}+\beta \cdot w_{i n}+\delta \cdot \eta_{i t}+\epsilon_{i t},
$$

where win $_{i t}$ is a dummy variable that takes the value of one for individuals who obtain credit in month $t$ or earlier and zero for individuals who have not obtained credit yet. Adding group-time fixed effects $\left(\alpha_{g t}\right)$ is important to compare individuals within the same group who self-select and are selected based on the same criteria. All other variables are defined as before.

As described in Section 2, most groups allocate credit through a combination of auctions and lotteries. While the awarding of credit through lotteries is purely random and orthogonal to $\eta_{i t}$, the awarding of credit through auctions may depend on economic variables that could be correlated with $\eta_{i t}$, introducing the same estimation bias problem as in equation (1).

Estimating equation (2) on the subset of participants who obtain credit through lotteries does not resolve the problem. Each period, the pool of participants that have not received credit changes. In particular, individuals who remain in the pool have been unable to obtain credit through auctions. This could reflect individual characteristics that are correlated with the outcome of interest. For example, individuals may not bid in auctions because of adverse labor market shocks or a lack of labor market opportunities. The longer participants remain in the pool, the more severe these concerns become.

\subsection{Instrumental Variable Strategy}

To overcome endogeneity problems related to auctions, we implement an instrument variable strategy. Our data allows us to simulate consorcio groups as if all credit were allocated through lotteries. This allows us to determine which participants would have received credit in a given month if the group allocated all credit though lotteries. 
Specifically, for each group we translate the national lottery numbers into ticket numbers based on the group's algorithm. By doing so period by period, we obtain the schedule of credit allocation as if all credit were allocated through lotteries. For example, consider a group with 150 participants running for 50 months and allocating credit to three individuals each period, two based on auctions and one based on lotteries. By applying the algorithm to the national lottery number each month, we can replicate the allocation of credit as if one lottery were held each month, but no auction. This provides us with a group of 50 predicted lottery winners, determined by the outcomes of the national lottery. Due to the presence of auctions in real-world groups, the instrument is not perfectly correlated with winning a lottery. For example, an individual predicted to win the lottery may have obtained credit through an auction in a different period.

Static Specification We predict the lottery winners in each group by estimating the following first-stage regression

$$
\text { First-stage }: \text { win }_{i t}=\alpha_{i}+\alpha_{g t}+\iota \cdot \text { win } \operatorname{sim}_{i t}+\delta \cdot \eta_{i t}+\epsilon_{i t},
$$

where win $\operatorname{sim}_{i t}$ is a dummy variable that takes the value of one from the month an individual is predicted to obtain credit according to the group's algorithm and zero before. Since win simit is based on the outcomes of random lotteries, it is orthogonal to $\eta_{i t}$ conditional on comparing participants within the same group. As a consequence, in the second stage estimation

$$
\text { Second-stage }: Y_{i t}=\alpha_{i}+\alpha_{g t}+\beta \cdot \widehat{w i n}_{i t}+\delta \cdot \eta_{i t}+\epsilon_{i t},
$$

the predicted timing of access to credit through lotteries $\widehat{w i n}_{i t}$ is uncorrelated with $\eta_{i t}$ and only affects outcomes through its correlation with access to credit. This allows us to recover an unbiased estimate of $\widehat{\beta}$.

We present the results from the first stage estimation in equation (3a) for the full sample in Table 2. The results show that simulated lottery winners predict actual lottery winners with a 24.34 percentage-point accuracy. The Kleibergen-Paap Fstatistic of the instrument is 8272.91. To interpret the estimate in Table 2, note that an individual may have won a credit lottery without being predicted a winner by the algorithm. For example, an individual can win a lottery in a given month because the winning ticket number based on the algorithm won an auction in an earlier month. The simulated lottery would not have correctly predicted this lottery winner since it ignores auction results. Thus, the estimate in Table 2 implies that an individual is 24.34 percentage points more likely to have won a credit lottery if 
predicted by the simulated lotteries.

Dynamic Specification The static estimation in equation (3b) compares average levels of outcomes before and after treatment. ${ }^{12}$ To obtain a better understanding of the full dynamics and to be able to assess pre-treatment trends, we augment equations (3a) and (3b) to a dynamic specification

$$
\begin{gathered}
\text { First-stage }: \widehat{\operatorname{win}}_{i t}^{s}=\alpha_{i}+\alpha_{g t}+\cdot \sum_{s=-5}^{5} \iota_{s} \cdot \text { win } \operatorname{sim}_{i t}^{s}+\eta_{i t}+\epsilon_{i t}, \\
Y_{i t}=\alpha_{i}+\alpha_{g t}+\sum_{s=-5, t \neq-1}^{5} \beta_{s} \cdot \widehat{\operatorname{win}}_{i t}^{s}+\epsilon_{i t},
\end{gathered}
$$

where the variable $\widehat{w i n}_{i t}^{s}$ is the instrumental variable estimated in the first stage. We omit the year before an individual is predicted to obtain credit, which is equivalent to normalizing to zero in the year before they obtain credit. Thus, the estimates for $\beta_{s}$ compare the outcomes to the year before an individual is predicted to receive credit. We pool the years from five to ten years before and after individuals obtain credit into one estimate. The estimates for $\beta_{s}$ for $s \leq 4$ are identified by comparing individuals who have obtained credit to those who have not yet obtained credit. The estimation of $\beta_{5}$ implicitly assumes that labor market outcomes before and after obtaining credit do not vary with the timing of access to credit, i.e. the treatment effect for individuals receiving credit after four years does not differ from those obtaining credit earlier (Bandiera et al., 2017). This assumption is consistent with evidence presented in Section 5.4 that pre-treatment and post-treatment patterns are independent of the timing of access to credit.

\subsection{Identifying Assumptions}

For our estimation strategy to be valid, the source of variation in access to credit for investment in mobility should be uncorrelated with characteristics that affect

\footnotetext{
${ }^{12} \mathrm{~A}$ static estimation as in equation (3b) may overweight short-term effects of access to credit compared to long-term effects in estimating $\beta$ with staggered treatment. Long-term effects may even have a negative weight (Borusyak and Jaravel, 2018). Whether this is problematic depends on the nature of the treatment effect. For example, if treatment induces a one-time change in the outcome variable, but does not affect the long-term growth rate, weighting issues are less of a problem. In contrast, if treatment changes the growth rate of the outcome variable, weighting issues can become problematic.
} 
the outcomes of interest. Since the variation in credit access that we exploit results from the outcome of random lotteries, variation in individual mobility is orthogonal to individual characteristics that may be correlated with labor market outcomes.

If participants anticipate the timing of access to credit, outcomes may be affected even before they obtain access to credit. For example, individuals may exert less effort on their current job in anticipation of gaining access to credit for investment in individual mobility. We provide several pieces of evidence that our outcomes of interest are not sensitive to anticipated access to individual mobility in our analysis.

We show that pre-treatment trends evolve no differently for participants who obtain credit just after their group starts than for those who obtain credit towards the end of the group. This suggests that individuals do not experience significant changes to the outcomes we observe while waiting to be drawn in the lottery. Additionally, the design of the algorithm that links the national lottery numbers to ticket numbers in each group leads to diverging probabilities of winning the lotteries over time within the same group. We observe that outcomes are insensitive to large differences in the probability of obtaining credit in either the near or more distant future. This further suggests that the outcomes of interest are not affected by anticipation of access to credit for investment in individual mobility (see Section 5.3 for details).

\subsection{Interpretation}

Since we rely on an instrumental variable strategy, our results are local average treatment effects for individuals targeted by the instrument. Specifically, our estimates apply to consorcio participants who obtain credit for motorcycle purchase through lotteries rather than through auctions. Additionally, consorcio participants are a selected group of individuals. Our estimates apply to this group and may be different for the general population. By revealed preferences, consorcio participants expect to benefit from access to individual mobility, which may not apply to the same extent for the average individual in the population. In addition, our counterfactual is individuals who save toward investment in a motorcycle through a consorcio group. As discussed in Section 4.4, we find no evidence that participation in a consorcio group affects outcomes for individuals before they obtain credit.

In sum, our estimates apply to individuals who consider obtaining credit for investment in individual mobility to be beneficial to them, but are unable to invest in individual mobility instantly because they are credit constrained. Obtaining estimates for this group of individuals might be a virtue rather than a vice, since they are likely targets of policy interventions. For example, recent evidence by 
Beaman et al. (2020) suggests that return on capital is higher if it is targeted at individuals who self-select into credit markets. Moreover, the high participation rate in motorcycle consorcios in Brazil suggests that the combination of seeking to invest in individual mobility and credit constraints is quite common and applies to a significant share of the population.

Finally, our results should be interpreted as intent-to-treat estimates. Some participants stop making payments to the group before receiving credit and therefore will not receive credit. Since the decision to stop making payments is endogenous, we do not drop those individuals, but treat them as if they obtain credit when their number is drawn in the lottery. In our sample, 23.25 percent percent of participants do not receive credit when their ticket number is drawn due to missed payments. In addition, 11.31 percent of individuals default on their payments after they receive credit and lose access to the motorcycle. These individuals are only partially treated.

\section{Results}

Before reporting the results from our statistical analysis, we list the numbers of firms, jobs, and distinct occupations that are accessible at varying commuting distances around individuals' homes in Table 3. Individuals on average have access to 74 firms, 867 jobs and 60 different occupations within a $1 \mathrm{~km}$ commuting distance. The number of firms increases to 224 with 3089 jobs in 80 different occupations within a $5 \mathrm{~km}$ commuting distance, and to 802 firms with 12,522 jobs in 91 different occupations within a $20 \mathrm{~km}$ commuting distance. These numbers suggest that being able to engage in a geographically broader job search increases the scale and scope of available employment opportunities.

\subsection{Static Estimation}

We start by documenting the results from estimating equation (2) in Table 4, Panel $\mathrm{A}$ and equation (3b) in Panel B.

In columns I and II, we examine changes in commuting patterns. The estimate in Panel A, column I shows that commuting distance (the distance between an individual's home and their workplace) increases by 4.53 percent after an individual obtains credit for a motorcycle purchase. The IV estimate in Panel B is similar with 4.16 percent. The distance between an individual's workplace and the nearest bus stop increases by 5.32 percent after obtaining credit (Panel A, column II). The IV 
estimate is similar with 5.94 percent (Panel B, column II). These results suggest that access to credit for investment in individual mobility allows individuals to engage in a geographically broader job search and access employment opportunities that are further away from home and harder to access through public transportation.

Next, we assess whether being able to engage in a geographically broader job search affects employment rates and labor income in columns III and IV. We find that formal employment rates increase by 1.02 percentage points after individuals obtain credit (Panel A, column III), with a slightly larger IV estimate of 1.92 percentage points (Panel B, column III). Salaries increase by 4.34 percent after individuals obtain credit (Panel A, column IV). The IV estimate is slightly lower with 2.80 percent (Panel B, column IV). In columns V and VI, we relate changes in salaries to changes in commuting behavior. We find that a ten percent greater increase in commuting distance after obtaining access to credit for motorcycle purchase is associated with a 0.53 percent greater increase in salaries ( Panel B, column V). Similarly, a ten percent increase in the distance between an individual's workplace and the closest bus stop is associated with a 0.29 percent greater increase in salaries (Panel B, column VI). Together, the results show that access to credit for investment in individual mobility enables individuals to engage in a geographically broader job search, with positive implications for formal employment rates and labor income.

\section{$5.2 \quad$ Heterogeneous Treatment Effects}

In Table 5, we assess whether the effects of access to credit for investment in individual mobility vary with location-specific or individual-specific characteristics.

Location-Specific Characteristics We start by assessing how the effect of access to credit for investment in individual mobility varies with location-specific characteristics in Panel A. One additional bus line per $\mathrm{km}^{2}$ in a municipality is associated with a 5.04 percent smaller increase in commuting distance (column I), although the estimate is noisy and not statistically significant. We find no significantly different effect on the distance between workplace and the closest bus stop in column II. Formal employment rates (column III) and salaries (column IV) increase 4.73 percentage points and 1.47 percent less per additional bus line, respectively. Individuals' commuting distance increases by 0.66 percent less (column V), and the distance between their workplace and closest bus stop increases by 0.38 percent less (column VI) per additional firm located in the municipality in which an individual lives. Formal employment rates (column VII) and salaries (column VIII) increase by 0.64 percentage points and 0.23 percent less per additional firm, respectively. 
Individual-Specific Characteristics Next, we assess how the effect of access to credit for investment in individual mobility varies with individual-specific characteristics in Panel B. A ten percent lower initial salary is associated with a 1.98 percent greater increase in commuting distance after obtaining credit (column I) and a 2.19 percent greater increase in the distance between work and the nearest bus stop (column II). Moreover, a ten percent lower initial salary is associated with a 0.91 percentage points greater increase in formal employment (column III) and a 16.5 percent greater increase in salary (column IV). In addition, we find that commuting distance increases by 1.28 percent less per year of age (column $\mathrm{V}$ ) and distance between work and the nearest bus stop increases by 1.16 percent less per year of age (column VI). ${ }^{13}$ The effect of access to individual mobility on formal employment is 3.43 percentage points smaller per year of age (column VII), and the effect of access to individual mobility on salaries is 6.97 percent lower per year of age (column VIII).

Together these results suggest that obtaining access to credit for investment in individual mobility has greater effects on formal employment rates and labor income for young, low-income individuals living in areas with less developed public transportation and fewer local employment opportunities.

\subsection{Dynamic Estimation}

To examine the full dynamics of the treatment effect, we estimate the dynamic specification from equation (4b). We graphically depict the $\beta_{s}$ estimates with 95 percent confidence bounds in this section. The estimates and standard errors are tabulated in Table 6.

We start by depicting changes in commuting patterns. The plots in Figure 1 show that commuting distance does not change before individuals obtain credit. From the year when they obtain credit, commuting distance starts to increase by 4.60 percent relative to individuals who have not obtained credit. This difference continues to increase to 17.85 percent four years after obtaining credit. The long-run estimate for five to ten years after obtaining credit suggests that the increase in commuting distance is persistent in the long run at 21.84 percent. The plots in Figure 2 show no pre-treatment trends in the distance between an individual's workplace and the nearest bus stop. From the year that individuals obtain credit, the distance increases by 3.34 percent relative to individuals who have not obtained credit. This difference continues to increase to 13.25 percent four years after obtaining credit. The long-run

\footnotetext{
${ }^{13}$ The age effect is not driven by when participants obtain credit. Controlling for the timing of access to credit (time since the group started) does not affect the results.
} 
estimate for five to ten years after obtaining credit shows that the increase in the distance between workplace and the closest bus stop is persistent at 13.08 percent.

The results in Figure 3 show no pre-treatment trends in formal employment rates. In the year of obtaining credit, formal employment increases by 1.84 percentage points relative to individuals who have not obtained credit. This difference stays at 1.61 percentage points four years after obtaining credit. The long-run estimate for five to ten years after obtaining credit shows that the increase in formal employment rates is permanent at 2.29 percentage points. The results in Figure 4 show no pretreatment trend in salaries. In the year of obtaining credit, salaries increase by 4.06 percent relative to individuals who have not obtained credit. This difference continues to increase to 10.57 percent four years after obtaining credit. The long-run estimate for five to ten years after obtaining credit shows that the salary increase is persistent in the long run at 17.91 percent.

Altogether, these results suggest that access to credit for investment in mobility leads to a permanent increase in the geographic scope of available employment opportunities, which in turn leads to higher rates for formal employment and salaries.

\subsection{Timing}

Finally, we examine whether the effect of access to credit for investment in individual mobility on labor market outcomes varies with the timing of access to credit. Individuals may seek access to credit for investment in individual mobility in response to labor market opportunities. If these are transitory, labor market effects may be weaker for individuals who obtain credit towards the end of the group. In Table 7, we list the marginal effect of obtaining credit one year later, that is the difference in the treatment effect if access to credit for investment in mobility occurs one year later.

In columns I and II, we find that commuting patterns do not show significant differences for individuals who obtain access to credit one year earlier or later. Similarly, we observe no economically meaningful differences in the effect of obtaining credit one year earlier or later on formal employment rates in column III. For salaries, we find that individuals who obtain credit for investment in individual mobility one year later exhibit a slightly smaller increase in salary in the first four years after obtaining credit by on average about 0.2 percent per year. However, this difference is economically negligible relative to the overall increase in salaries after obtaining credit, and in the long run the difference reverses, with obtaining credit one year later being associated with a 0.56 percent smaller increase in salary. Together, the results suggest that the treatment effect of obtaining access to credit for invest- 
ment in mobility is largely independent of timing. ${ }^{14}$ This suggests that individuals' access to distant labor markets is persistently restricted until access to credit for investment in mobility enables them to expand the geographic scope of labor market access. This pattern resembles the idea of a poverty trap in which a lump-sum investment is required to reach a higher growth trajectory (Dasgupta and Ray, 1986; Banerjee and Newman, 1993; Galor and Zeira, 1993).

\section{Returns to Individual Mobility}

In this section, we estimate the value and return to capital for investment in individual mobility, similarly to Bandiera et al. (2017). We focus on changes in salaries. Access to credit for investment in individual mobility may provide additional benefits, for example reducing commuting time or improving access to education (Muralidharan and Prakash, 2017). Thus, our estimates are likely to be an underestimate of the total value of access to credit for investment in individual mobility.

\subsection{Base Estimate}

The total effect of individual mobility on expected labor income $\mathbb{E}[\pi]$ can be computed as:

$$
\mathbb{E}[\pi]=\sum_{s=0}^{T} \frac{\mathbb{E}\left[\log \left(S_{s}^{M}\right)-\log \left(S_{s}^{B}\right)\right] \cdot(1-\tau)}{(1+r)^{s}}
$$

where $T$ is the last period in which an individual is observed, $S_{s}^{M}$ and $S_{s}^{B}$ are the salaries with and without access to individual mobility, respectively, $\tau$ is the income tax rate, and $r$ is the (real) annual rate to discount future income. The definition of $\mathbb{E}[\pi]$ in equation (5) ensures that it is normalized to zero if access to credit for investment in individual mobility has no effect on salaries.

Our estimates for $\beta_{s}$ can be interpreted as estimates for $\mathbb{E}\left[\log \left(S_{s}^{M}\right)-\log \left(S_{s}^{B}\right)\right]$ for consorcio participants. Our final estimate $\beta_{5}$ includes years up to ten years after obtaining credit. Due to the length of our sample period, we cannot estimate $\beta_{s}$ for $s>10$. Thus, we limit $T$ to 10 years after gaining access to credit for investment in individual mobility. There is no obvious rate to use for discounting cash flows from investment in individual mobility. The real deposit and ten-year government

\footnotetext{
${ }^{14}$ Nevertheless, obtaining credit earlier is valuable since the positive treatment effect occurs earlier in an individual's career, leading to a higher aggregate salary increase.
} 
bond rate are 4.56 and 6.46 percent during our sample period, respectively. Since investment in individual mobility justifies adding a risk-premium to the discount rate we settle for a rate of 10 percent. It is straightforward to adjust the computations for alternative rates.

Based on an average income tax rate of 8 percent for motorcycle consorcio participants and our estimates for $\beta_{s}$ (see Table 8), assuming a real discount rate of $r=0.1$, the income effect of access to individual mobility equals 0.70 annual salaries.

Access to individual mobility requires an initial investment. In the simplest case in which an individual purchases a motorcycle outright, the net benefit of individual mobility minus costs can be computed as

$$
\mathbb{E}\left[\pi_{n e t}\right]=\mathbb{E}[\pi]-I
$$

where $I$ is the cost of the motorcycle as a fraction of the base salary. The average cost of a motorcycle across all of our groups divided by the average pre-credit salary of consorcio participants is 0.46 . Thus, the net income effect of investment in individual mobility is $0.70-0.46=0.24$ annual salaries for a real discount rate of $r=0.1$.

An alternative way to compute the return on investment in individual mobility, which facilitates comparison with other types of investment and does not require an assumption on the discount rate, is the internal rate of return (IRR). The IRR can be computed by setting equation (6) to zero:

$$
0=\sum_{s=0}^{10} \frac{\mathbb{E}\left[\log \left(S_{s}^{M}\right)-\log \left(S_{s}^{B}\right)\right](1-\tau)}{(1+I R R)^{s}}-I
$$

Solving equation (7), we obtain an IRR of 16.94 percent. Thus, investment in individual mobility generates a real annual return of 16.94 percent over 10 years.

\subsection{Long-term Projections}

With some additional assumptions, we can provide an estimate of the income effect of access to credit for investment in individual mobility in the long-term beyond 10 years after receiving credit. The simplest assumption is that the expected salary wedge $\mathbb{E}\left[\log \left(S_{s}^{M}\right)-\left(S_{s}^{B}\right)\right]$ stays constant for $s>10$ as in Bandiera et al. (2017). This might be conservative given that the gradient of $\beta_{s}$ with respect to $s$ is positive in the observable range.

The average individual in our sample is 35 years old when they obtain credit 
for motorcycle purchase and the legal pension age for men is 65 in Brazil. Thus, individuals expect to be in employment for an additional 30 years. If we extend equation (5) to $s=30$, the additional salary due to access to individual mobility over an individual's career amounts to 1.05 annual salaries assuming $r=0.1$.

Taking into account the long-term costs of access to a motorcycle requires an assumption about the expected lifespan of a motorcycle. According to the distribution of motorcycle age in Brazil, the maximum age is 20 years, the $95^{\text {th }}$ percentile is 16 years, and the $90^{\text {th }}$ percentile is 13 years. Given these numbers, it seems reasonable to assume that individuals need to purchase another motorcycle after about 15 years. Taking into account the cost of the initial purchase and an additional purchase after 15 years in equation (6), we obtain a net income effect of $1.05-0.46-0.07=0.52$ annual salaries for $r=0.1$.

With these assumptions, the long-term IRR in equation (7) is 15.60 percent. This suggests that access to credit for investment in individual mobility yields an annual return of 15.60 percent over 30 years.

Financing The costs of investment in individual mobility depend on the financing. For example, in the case of consorcio groups, most participants do not obtain credit for investment in a motorcycle at time $s=0$ but at equal rates over $M$ months, which also include fees, akin to an interest rate $f$. Thus, the cost part in equation (6) changes to $\sum_{s=0}^{M} I / M \cdot(1+f)$ in consorcio groups. ${ }^{15}$

For a rate of $r=0.1$, financing a motorcycle through a consorcio with an average fee of $f=0.16$ rather than outright purchase adds 0.018 annual wages to the costs of investment in a motorcycle.

Intent-to-Treat As discussed in Section 4.4, our estimates for $\beta_{s}$ are intent-totreat estimates since 23.25 percent of consorcio participants default before obtaining credit and 11.31 percent default after obtaining credit. Thus, 23.25 percent of participants do not obtain access to credit for investment in individual mobility, and 11.31 percent benefit from access to individual mobility for a limited time period only. We can adjust the intent-to-treat estimates accordingly, by multiplying the $\beta_{s}$ estimates with $1 /\left(1-x_{s}\right)$, where $x_{s}$ is the fraction of individuals who default by period $s$. We list the values for $x_{s}$ in Table 8 .

Adjusting the intent-to-treat values, the value of access to individual mobility changes from 0.70 to 1.05 annual salaries, which net of costs amounts to 0.59 annual

\footnotetext{
${ }^{15}$ Here, we abstract from reserve fund payments which are a very peculiar feature of consorcio groups.
} 
salaries, and implies an IRR of investment in individual mobility of 26.10 percent.

\section{$7 \quad$ Remaining Issues}

In this section, we discuss potential remaining concerns with our empirical analysis in the paper and the interpretation of the results.

\subsection{Measurement}

We start by strengthening the validity of some of the key variables in our empirical analysis by performing a set of robustness checks.

Distance Measure The precision of our location measure is at the zip code level. For the distance metrics to closely capture changes in commuting patterns, the center of the zip code should be a reasonable proxy for the actual location of an individual. The area covered by a zip code varies widely across Brazil. In sparsely populated rural areas, zip codes cover a large geographic area and contain many inhabitants. In contrast, in densely populated urban areas, zip codes cover smaller geographic areas and have fewer inhabitants. Specifically, each municipality with less than 50,000 inhabitants is assigned one zip code, whereas municipalities with more than 50,000 inhabitants are divided into multiple zip codes.

As a consequence, for small municipalities, changes in distance effectively capture commuting to a more distant municipality and the distance measure is noisy. In the full sample, the median zip code covers an area of 357 square kilometers and 8,942 inhabitants. To ensure that our estimates are not biased due to this issue, we reestimate the commuting distance results for the sample of municipalities with a population of more than 50,000 for which the median population per zip code is 133 and the median area covered is 0.98 square kilometers.

The results are gathered in Table 9, columns I and II. The results are qualitatively identical and quantitatively similar for these municipalities for which the location measures are much more precise. If anything, the results are slightly stronger and are estimated with less noise.

Informal Labor Markets We only observe formal employment. A significant share of the labor market in Brazil is informal. Thus, changes in formal employment may capture transitions from informal to formal employment rather than from 
unemployment to employment. ${ }^{16}$ Similarly, changes in salaries could be driven by workers substituting a job in the informal sector with a formal one. Since changes in salaries are only captured conditional on formal employment before and after obtaining access to credit for investment in a motorcycle, the concern related to informal employment is that workers might substitute an informal second job with a formal one.

To assess the role of informal labor markets, we exploit heterogeneity in labor market informality across Brazil. Labor market informality is highly heterogeneous across Brazil. In some municipalities labor market informality is below 10 percent, whereas in other municipalities it exceeds 60 percent. We re-estimate our salary results for municipalities with below-median levels of labor market informality in Table 9, column III. We find that the increase in salaries after access to individual mobility is even stronger in municipalities with below-median levels of labor market informality, which suggests that the base results are not driven by substitution between informal and formal jobs.

\subsection{Anticipation Effects}

Labor market outcomes for consorcio participants may be affected by anticipating access to credit for investment in a motorcycle. For example, participants may shirk on their job or invest less effort in searching for new employment if they anticipate imminent access to credit. From the outset, it is important to note that this may just be the correct counterfactual capturing variation in labor market outcomes for individuals who seek access to credit for investment in individual mobility. Additionally, the results in Section 5.4 show no different pre-treatment trends for individuals who gain access to individual mobility at different times. If there are strong anticipation effects, we should see different pre-treatment trends for participants who obtain credit later, since over time individuals become increasingly likely to obtain access to credit sooner rather than later.

To directly test for anticipation effects, we exploit the fact that depending on the ticket numbers that obtained credit in previous periods, the conditional probability of winning the lottery in future periods diverges for participants in the same group. This follows from the design of the algorithms that determine the winning ticket. Suppose a group has 100 members and allocates credit to two participants each period, one through lottery and one through auction. In the first period, each participant has a one in a hundred chance of winning the lottery. Now, suppose that

\footnotetext{
${ }^{16}$ Since the distance metrics are conditional on formal employment, they are less subject to concerns about labor market informality.
} 
after 25 periods, the ticket numbers 11, 12, 13, 17, and 20 have not been awarded credit, whereas ticket numbers 14, 15, 16, 18, and 19 have been awarded credit in a previous period. In this case, ticket number 12 has a two percent probability of winning the lottery in period 26, whereas ticket number 13 has a four percent chance since it is declared winner of the lottery if the algorithm lands on either 13 or 14. Ticket number 17 has an eight percent chance since it wins the lottery if the algorithm lands on number 15, 16, 17, or 18 .

In Table 10, we examine whether facing a different probability of gaining access to credit sooner rather than later affects participants' labor market outcomes. Specifically, we compare labor market outcomes for participants in the same group who have not yet received credit, but have different likelihoods to obtain credit sooner rather than later. We find that commuting patterns and labor market outcomes are insensitive to differences in the probability of gaining access to credit sooner rather than later. This suggests that labor market outcomes are not affected by anticipation of access to credit to invest in individual mobility.

\section{Conclusion}

Exploiting randomized time-series variation in access to credit tied to the purchase of motorcycles through a group-lending mechanism in Brazil (consorcio), we document that access to credit for investment in individual mobility yields high and persistent returns. Consistent with a geographically broader job search, we observe that individuals find jobs further away from home and public transportation. The effects are stronger in areas with less developed public transport and scarce local labor markets, and younger and lower-income individuals.

Among various interventions explored to boost the economic development of lowincome households, much hope has been placed on the transformative power of financial access. Yet, existing studies typically document that the returns to capital are meager and access to finance rarely has transformative effects. Our findings suggest that extending credit for investment in mobility can generate large returns. It is often assumed that access to labor markets does not require a large upfront investment (e.g. Banerjee and Newman 1993). Our results suggest that overcoming spatial constraints in labor market access may require a large upfront investment and therefore access to capital. This insight is supported by recent evidence in Banerjee, Duflo, and Sharma (2020) that positive long-term effects on labor income from a cash grant program in West Bengal are linked to migration to more distant urban centers. Our results also resonate with theories of spatial mismatch (Kain 
1968) and suggest that policies to increase individuals' mobility (Fan 2012) may have important implications for labor market access.

Recent evidence by Beaman et al. (2020) suggests who return on capital is higher if it is targeted at individuals that self-select into credit markets. This suggests that mechanisms that can target this population generate higher returns on capital. This poses a practical challenge to policy makers and may be an important aspect to consider in designing mechanisms and policies. A potential upside of marketbased solutions is that, to be sustainable, they endogenously require targeting of populations that generate high-returns, as in the case of consorcios in Brazil. Identifying populations that generate high returns on capital and designing policies and mechanisms to target them is a promising avenue for future research. For example, Hussam, Rigol, and Roth (2020) show that eliciting community information can help identify high ability entrepreneurs who generate high returns on investment.

Our findings have broader policy implications. For example, our results have implications for urban and infrastructure planning to mitigate spatial mismatch between workers and firms. Additionally, our results suggest that providing access to mobility for job-seeker significantly improves their labor market prospects, for example in the context of welfare-to-work programs. Similarly, as well as facilitating access to credit for investment in individual mobility, it may be beneficial to allow financially distressed individuals to maintain access to individual mobility, for example through asset exemption rules in bankruptcy proceedings.

\section{References}

ABAC, 2017, Sistema de consorcios, Annual Report 2016/17, Associacao Brasileira de Administradoras de Consorcios.

Angelucci, Manuela, Dean Karlan, and Jonathan Zinman, 2015, Microcredit impacts: Evidence from a randomized microcredit program placement experiment by Compartamos Banco, American Economic Journal: Applied Economics 7, $151-82$.

Attanasio, Orazio, Britta Augsburg, Ralph De Haas, Emla Fitzsimons, and Heike Harmgart, 2015, The impacts of microfinance: Evidence from joint-liability lending in Mongolia, American Economic Journal: Applied Economics 7, 90-122.

Augsburg, Britta, Ralph De Haas, Heike Harmgart, and Costas Meghir, 2015, The impacts of microcredit: Evidence from Bosnia and Herzegovina, American Economic Journal: Applied Economics 7, 183-203. 
Bandiera, Oriana, Robin Burgess, Narayan Das, Selim Gulesci, Imran Rasul, and Munshi Sulaiman, 2017, Labor markets and poverty in village economics, Quarterly Journal of Economics 132, 811-870.

Banerjee, Abhijit, Emily Breza, Esther Duflo, and Cynthia Kinnan, 2019, Can microfinance unlock a poverty trap for some entrepreneurs?, Working Paper 26346, National Bureau of Economic Research.

Banerjee, Abhijit, Esther Duflo, Rachel Glennerster, and Cynthia Kinnan, 2015, The miracle of microfinance? Evidence from a randomized evaluation, American Economic Journal: Applied Economics 7, 22-53.

Banerjee, Abhijit, Esther Duflo, and Garima Sharma, 2020, Long-term effects of the targeting the ultra poor program, Working Paper 28074, National Bureau of Economic Research.

Banerjee, Abhijit V., and Andrew F. Newman, 1993, Occupational choice and the process of development, Journal of Political Economy 101, 274-298.

Beaman, Lori, Dean Karlan, Bram Thuysbaert, and Christopher Udry, 2020, Selection into credit markets: Evidence from agriculture in Mali, Working paper.

Besley, Timothy, and Stephen Coate, 1995, Group lending, repayment incentives and social collateral, Journal of Development Economics 46, 1 - 18.

Besley, Timothy, Stephen Coate, and Glenn Loury, 1993, The economics of rotating savings and credit associations, The American Economic Review 83, 792-810.

Borusyak, Kirill, and Xavier Jaravel, 2018, Revisiting event study designs, Working paper, Harvard University.

Breza, Emily, and Cynthia Kinnan, 2020, Measuring the equilibrium impacts of credit: Evidence from the Indian microfinance crisis, Working paper, NBER.

Bryan, Gharad, Shyamal Chowdhury, and Ahmed Mushfiq Mobarak, 2014, Underinvestment in a profitable technology: The case of seasonal migration in Bangladesh, Econometrica 82, 1671-1748.

Cai, Jing, and Adam Szeidl, 2019, Direct and indirect effects of financial access on SMEs, Working paper, NBER.

Campbell, Dennis, Asis Martinez-Jerez, and Peter Tufano, 2012, Bouncing out of the banking system: An empirical analysis of involuntary bank account closures, Journal of Banking and Finance 36, 1224-1235. 
Carrell, Scott, and Jonathan Zinman, 2014, In harm's way? Payday loan access and military personnel perfomance, Review of Financial Studies 27, 2805-2840.

Crepon, Bruno, Florencia Devoto, Esther Duflo, and William Pariente, 2015, Estimating the impact of microcredit on those who take it up: Evidence from a randomized experiement in Morocco, American Economic Journal: Applied Economics $7,123-150$.

Dasgupta, Partha, and Debraj Ray, 1986, Inequality as a Determinant of Malnutrition and Unemployment: Policy, The Economic Journal 96, 1011-1034.

Fan, Yingling, 2012, The planners' war against spatial mismatch: Lessons learned and ways forward, Journal of Planning Literature 27, 153-169.

Galor, Oded, and Joseph Zeira, 1993, Income distribution and macroeconomics, Review of Economic Studies 60, 35-52.

Gertler, Paul, Brett Green, and Catherine Wolfram, 2021, Unlocking access to credit with digital collateral, Working paper.

Hussam, Reshmaan N., Natalia Rigol, and Benjamin N. Roth, 2020, Targeting high ability entrepreneurs using community information: Mechanism design in the field, American Economic Review .

Ihlanfeldt, Keith R., and David L. Sjoquist, 1998, The spatial mismatch hypothesis: A review of recent studies and their implications for welfare reform, Housing Policy Debate 9, 849-892.

Kaboski, Joseph P., and Robert M. Townsend, 2012, The impact of credit on village economies, American Economic Journal: Applied Economics 4, 98-133.

Kain, John F., 1968, Housing segregation, negro employment, and metropolitan decentralization, Quarterly Journal of Economics 82, 175-197.

Karlan, Dean, and Jonathan Zinman, 2010, Expanding credit access: Using randomized supply decisions to estimate the impacts, Review of Financial Studies $23,433-464$.

Karlan, Dean, and Jonathan Zinman, 2011, Microcredit in theory and practice: Using randomized credit scoring for impact evaluation, Science 332, 1278-1284.

Marinescu, Ioana, and Roland Rathelot, 2018, Mismatch unemployment and the geography of job search, Technical Report 3. 
Meager, Rachael, 2019, Understanding the average impact of microcredit expansions: A Bayesian hierarchical analysis of seven randomized experiments, American Economic Journal: Applied Economics 11, 57-91.

Meager, Rachael, 2020, Aggregating distributional treatment effects: A Bayesian hierarchical analysis of the microcredit literature.

Melzer, Brian T., 2011, The real costs of credit access: Evidence from the payday lending market, Quarterly Journal of Economics 126, 517-555.

Morgan, Donald P., Michael R. Strain, and Ihab Seblani, 2012, How payday credit affects overdrafts and other outcomes, Journal of Money, Credit and Banking 44, $510-531$.

Morse, Adair, 2011, Payday lenders: Heroes or villains, Journal of Financial Economics 102, 28-44.

Muralidharan, Karthik, and Nishith Prakash, 2017, Cycling to school: Increasing secondary school enrollment for girls in India, American Economic Journal: Applied Economics 9, 321-350.

Skiba, Paige M., and Jeremy Tobacman, 2019, Do payday loans cause bankruptcy?, The Journal of Law and Economics 62, 485-519.

Tarozzi, Alessandro, Jaikishan Desai, and Kristin Johnson, 2015, The impacts of microcredit: Evidence from Ethiopia, American Economic Journal: Applied Economics $7,54-89$.

Zinman, Jonathan, 2010, Restricting consumer credit access: Household survey evidence on effects around the Oregon rate cap, Journal of Banking and Finance 34, $546-556$. 
Figure 1: Commuting Distance

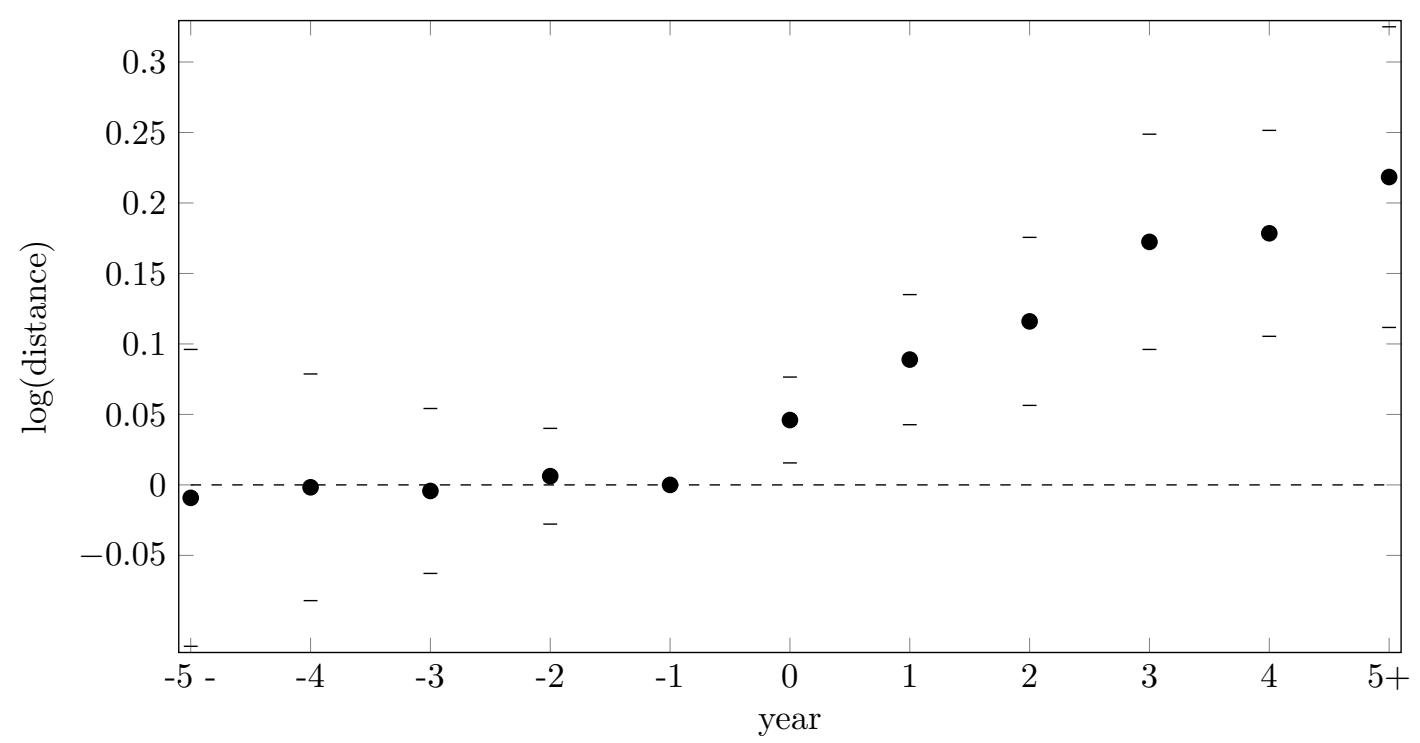

This figure depicts the estimates from equation (4b) with the log distance between an individual's workplace and their home as the dependent variable with 95 percent confidence bounds.

Figure 2: Distance to Public Transportation

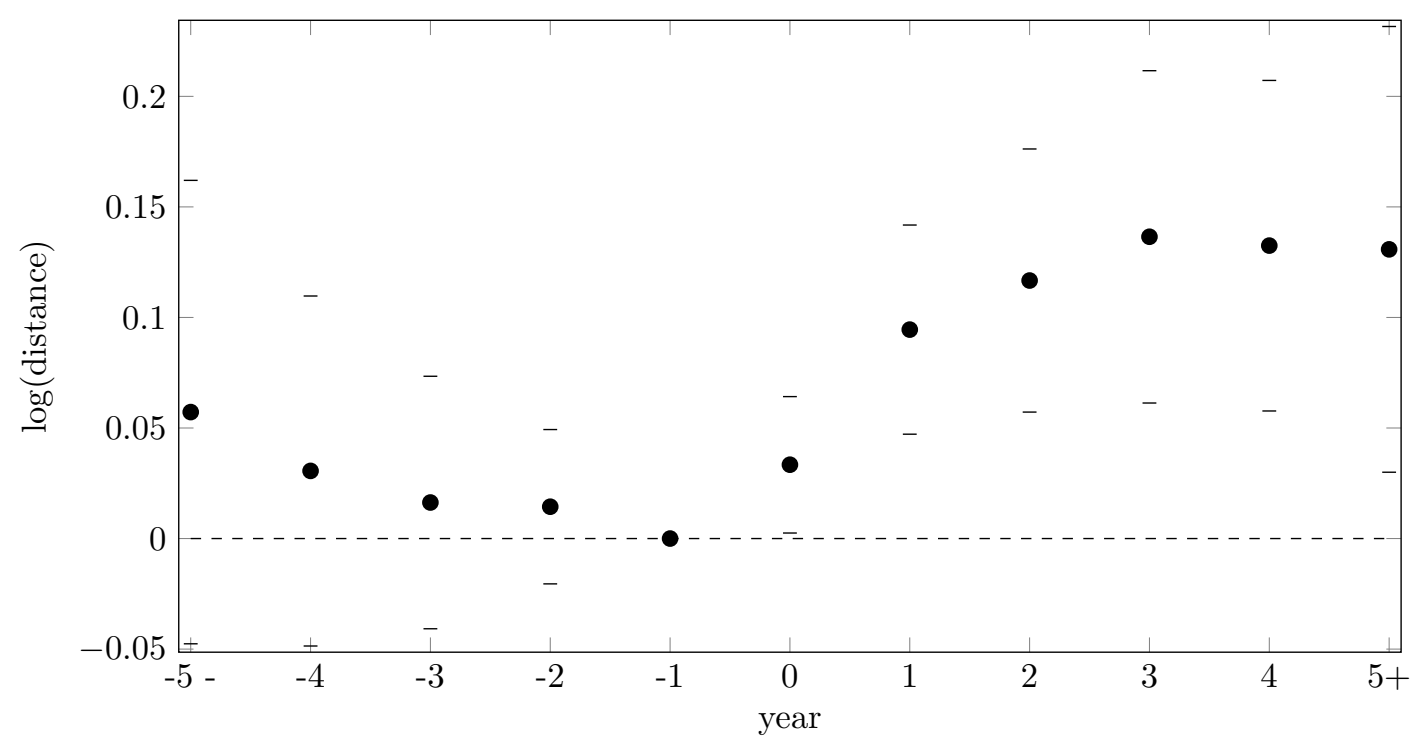

This figure depicts the estimates from equation (4b) with the log distance between an individual's workplace and the nearest bus stop as the dependent variable with 95 percent confidence bounds. 
Figure 3: Formal Employment

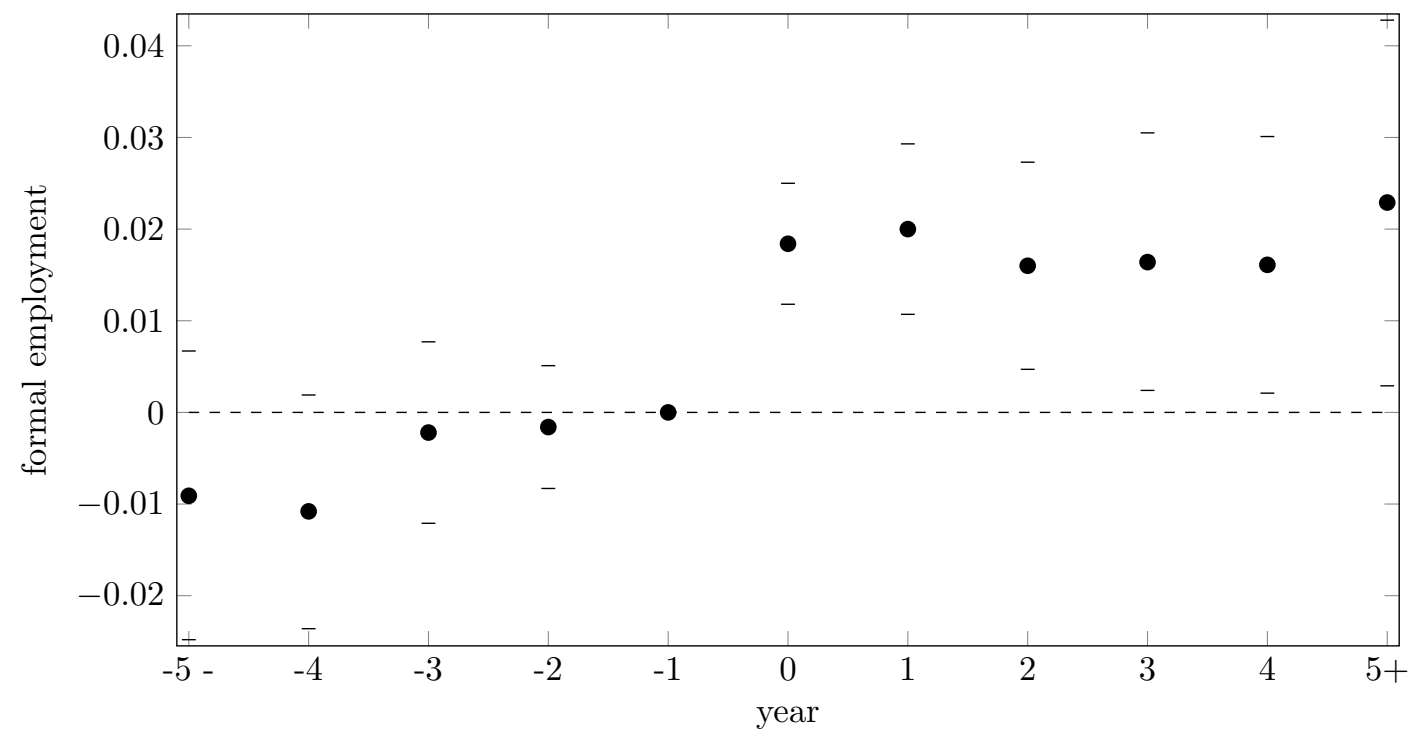

This figure depicts the estimates from equation (4b) with a dummy variable that takes the value of one if an individual is formally employed and zero otherwise as the dependent variable with 95 percent confidence bounds.

Figure 4: Salary

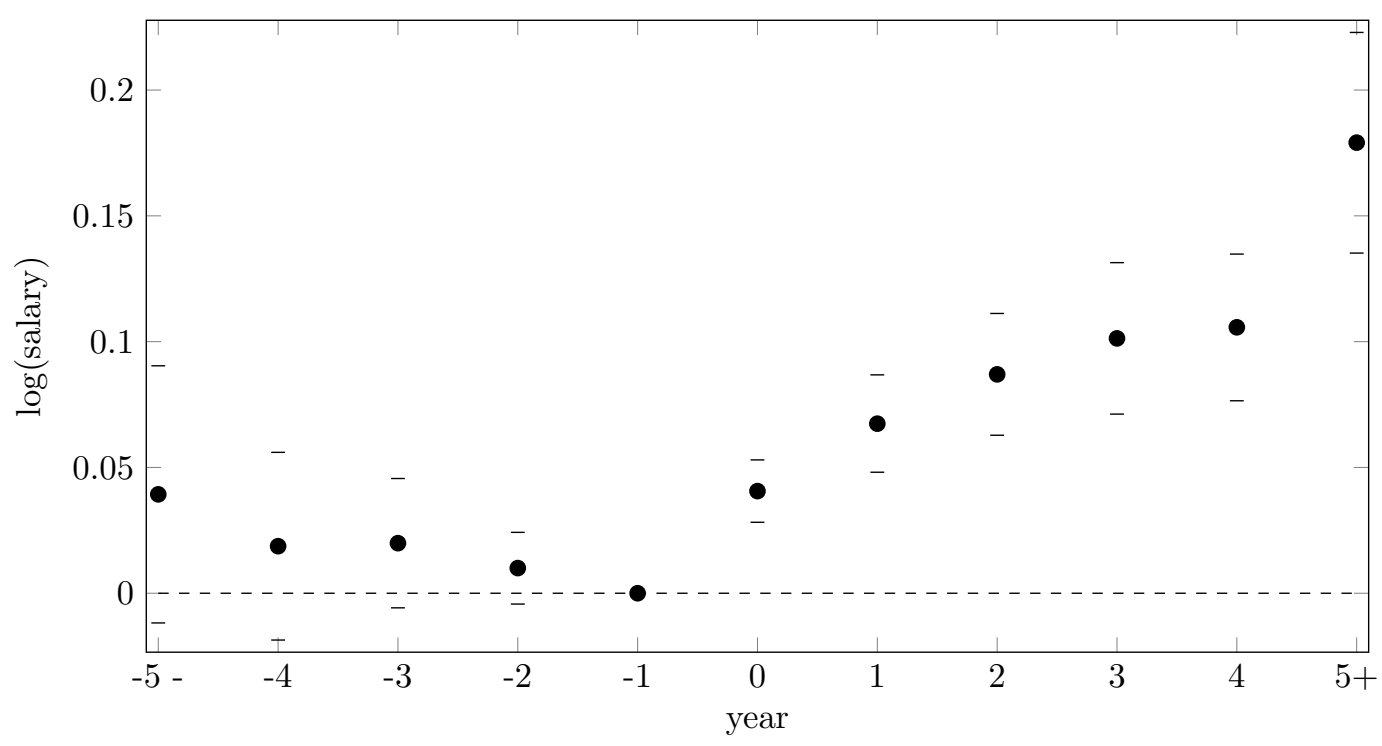

This figure depicts the estimates from equation (4b) with the log salary as the dependent variable with 95 percent confidence bounds. 
Table 1: Descriptive Statistics

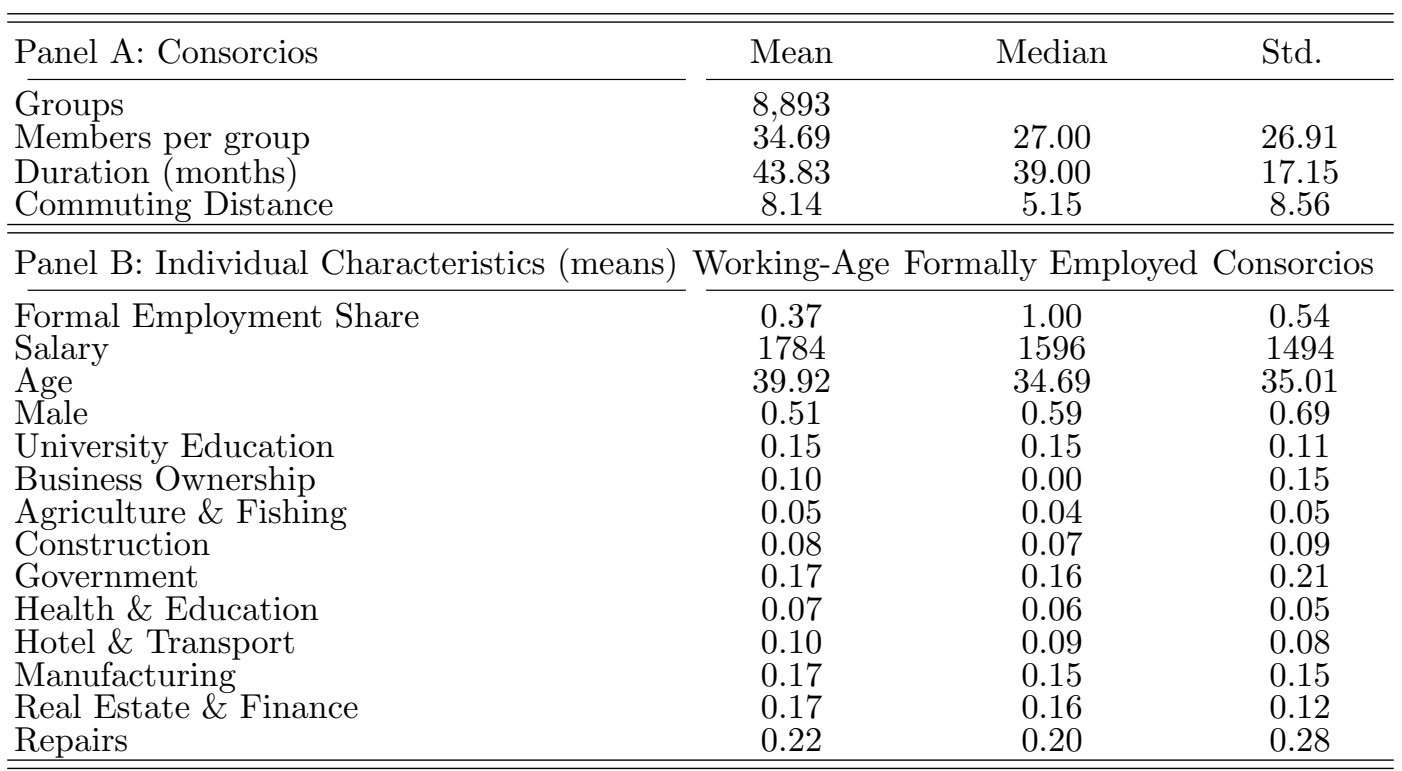

This table provides descriptive statistics. Panel A provides descriptive statistics on the number of consorcio groups, the number of members per group, the duration of the groups, and the average pre-treatment commuting distance of formally employed individuals. Panel B depicts descriptive statistics for all working-age individuals, all formally employed workers, and consorcio participants.

\section{Table 2: First-Stage Estimation - Full Sample}

\begin{tabular}{lc}
\hline Dep. Var.: & win $_{i t}$ \\
\hline win sim & \\
& $0.2434^{* * *}$ \\
& {$[0.0027]$} \\
\hline Group-Year FE & yes \\
Individual FE & yes \\
Clustered SE & group \\
\hline Observations & $44,912,112$ \\
$R^{2}$ & 0.644 \\
K-P F-Stat & 8272.91 \\
\hline \hline
\end{tabular}

This table reports the results from the first stage estimation in equation (3a) for the full sample. Standard errors are reported in parentheses. *** denotes statistical significance at the $1 \%$ level.

\section{Table 3: Spatial Mobility and Employment Opportunities}

\begin{tabular}{|c|c|c|c|c|c|c|c|}
\hline Commuting Distance & $1 \mathrm{~km}$ & $3 \mathrm{~km}$ & $5 \mathrm{~km}$ & $10 \mathrm{~km}$ & $20 \mathrm{~km}$ & $50 \mathrm{~km}$ & $100 \mathrm{~km}$ \\
\hline Number of Firms & 74 & $\overline{143}$ & $\overline{224}$ & 431 & 802 & $\overline{1399}$ & 2342 \\
\hline Number of Jobs & 867 & 1863 & 3089 & 6400 & 12522 & 22100 & 36336 \\
\hline Number of Occupations & 60 & 73 & 80 & 87 & 91 & 96 & 101 \\
\hline
\end{tabular}

This table depicts the average numbers of firms, jobs, and distinct occupations at different commuting distances for the average individual in our sample. 
Table 4: Static Specification

\begin{tabular}{|c|c|c|c|c|c|c|}
\hline & $\mathrm{I}$ & II & III & IV & $\mathrm{V}$ & VI \\
\hline & \multicolumn{6}{|c|}{ Panel A: OLS } \\
\hline Dep. Var.: & $\log \left(\right.$ distance $_{i t}$ & $\log (\text { bus distance })_{i t}$ & formal $_{i t}$ & \multicolumn{3}{|c|}{$\log (\text { salary })_{i t}$} \\
\hline $\begin{array}{l}\operatorname{win}_{i t} \\
\operatorname{win}_{i t} * \Delta \log (\text { distance })_{i}\end{array}$ & $\begin{array}{c}0.0453^{* * *} \\
{[0.0054]}\end{array}$ & $\begin{array}{c}0.0532^{* * *} \\
{[0.0056]}\end{array}$ & $\begin{array}{c}0.0102^{* * *} \\
{[0.0013]}\end{array}$ & $\begin{array}{c}0.0434^{* * *} \\
{[0.0032]}\end{array}$ & $\begin{array}{c}-0.0166^{* *} \\
{[0.0076]} \\
0.0587^{* * *} \\
0.0128]\end{array}$ & $\begin{array}{c}-0.0085^{*} \\
{[0.0049]}\end{array}$ \\
\hline $\operatorname{win}_{i t} * \Delta \log (\text { busdist })_{i}$ & & & & & & $\begin{array}{c}0.0259^{* * *} \\
{[0.0038]}\end{array}$ \\
\hline $\begin{array}{l}\text { Observations } \\
R^{2}\end{array}$ & $\begin{array}{c}5,875,872 \\
0.881\end{array}$ & $\begin{array}{c}9,188,563 \\
0.870\end{array}$ & $\begin{array}{c}44,912,112 \\
0.486\end{array}$ & $\begin{array}{c}17,393,949 \\
0.824\end{array}$ & $\begin{array}{c}1,070,263 \\
0.948\end{array}$ & $\begin{array}{c}1,785,379 \\
0.926\end{array}$ \\
\hline
\end{tabular}

Panel B: IV

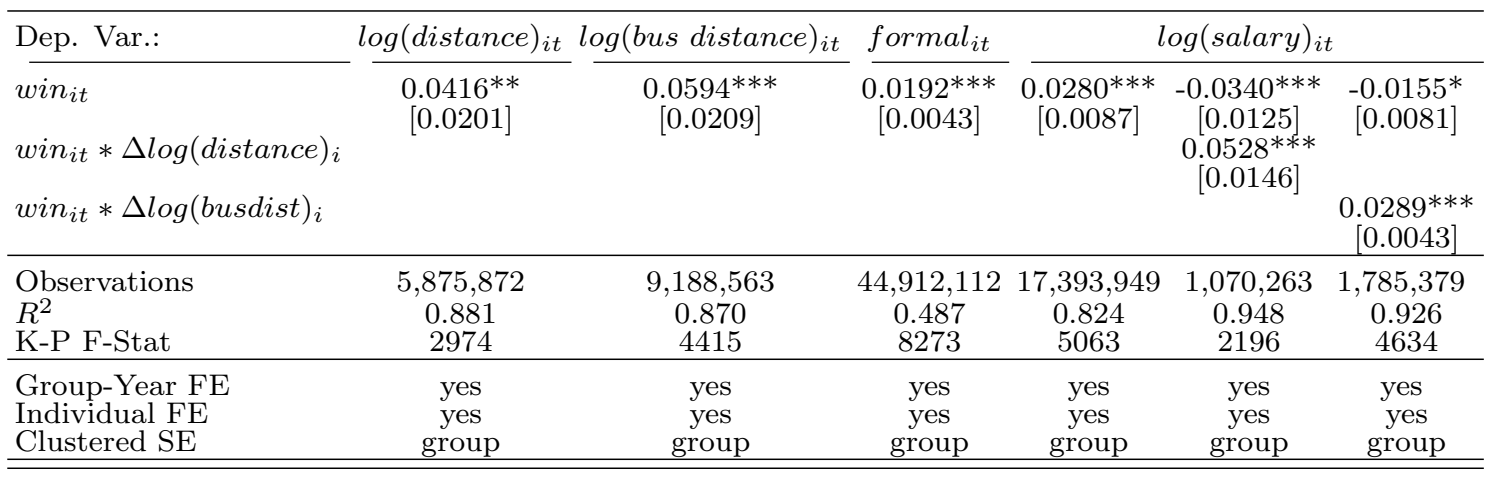

This table depicts the results from equation (2) in Panel A and the second stage estimation in equation (3b) in Panel B. The dependent variable is the log distance between individual $i$ 's home and workplace in month $t$ in column $\mathrm{I}$, the $\log$ distance between individual $i$ 's workplace and the nearest bus stop in column II, a dummy variable that takes the value of one if individual $i$ is formally employed in month $t$ and zero otherwise in column III, and the log of individual $i$ 's salary in month $t$ in columns IV to VI. The variable win $_{i t}$ takes the value of one from the month an individual receives credit for motorcycle purchase and zero before. The variable $\Delta \log (\text { distance })_{i}$ is the log difference in an individuals commuting distance after compared to before obtaining credit. The variable $\Delta \log (\text { bus distance })_{i}$ is the $\log$ difference in the distance between an individual's workplace and the nearest bus stop after compared to before obtaining credit. Standard errors are reported in parentheses. The bottom of the table provides information on fixed effects and the clustering of standard errors. $* * *, * *$, and $*$ denote statistical significance at the $1 \%, 5 \%$, and $10 \%$ levels, respectively. 


\section{Table 5: Heterogeneous Treatment Effects}

\begin{tabular}{|c|c|c|c|c|c|c|c|c|}
\hline & $\mathrm{I}$ & II & III & IV & $\mathrm{V}$ & VI & VII & VIII \\
\hline & \multicolumn{8}{|c|}{ Panel A: Location-Specific Characteristics } \\
\hline & \multicolumn{4}{|c|}{ Public Transport } & \multicolumn{4}{|c|}{ Employment Opportunities } \\
\hline Dep. Var.: & \multicolumn{2}{|l|}{$-\underline{\log \left(\text { distance }_{i t} l\right.} l$} & \multirow{3}{*}{$\begin{array}{c}\text { formal }_{i t} \\
0.0498^{* * *} \\
{[0.0473]} \\
-0.0473^{* * *} \\
{[0.0026]}\end{array}$} & \multirow{3}{*}{$\begin{array}{c}\log (\text { salary })_{i t} \\
0.0328^{* * *} \\
{[0.0095]} \\
-0.0147^{* *} \\
{[0.0065]}\end{array}$} & \multicolumn{2}{|c|}{$\log \left({\text { distance })_{i t}}_{\text {log }} \log (\text { bus distance })_{i t}\right.$} & \multirow{2}{*}{$\frac{\text { formal }_{i t}}{0.0891^{* * *}}$} & $\log (\text { salary })_{i t}$ \\
\hline $\begin{array}{l}\operatorname{win}_{i t} \\
\text { win }_{i t} * n b \text { bus lines }\end{array}$ & $\begin{array}{c}0.0629 * * \\
{[0.0271]} \\
-0.0504 \\
{[0.0349]}\end{array}$ & $\begin{array}{c}0.0652^{* * *} \\
{[0.0240]} \\
-0.0031 \\
{[0.0175]}\end{array}$ & & & $\begin{array}{c}0.0802^{* *} \\
{[0.0267]}\end{array}$ & $\begin{array}{c}0.0976^{* * *} \\
{[0.0253]}\end{array}$ & & $\begin{array}{c}0.0504^{* * *} \\
{[0.0110]}\end{array}$ \\
\hline$w_{i n} * n b$ firms $s_{m}$ & & & & & $\begin{array}{c}-0.0066^{* *} \\
{[0.0028]}\end{array}$ & $\begin{array}{c}-0.0038^{* *} \\
{[0.0015]}\end{array}$ & $\begin{array}{c}-0.0064^{* * *} \\
{[0.0002]} \\
\end{array}$ & $\begin{array}{c}-0.0023^{* * *} \\
{[0.0006]} \\
\end{array}$ \\
\hline $\begin{array}{l}\text { Observations } \\
R^{2} \\
\text { K-P F-Stat } \\
\end{array}$ & $\begin{array}{c}5,190,690 \\
0.881 \\
1406 \\
\end{array}$ & $\begin{array}{c}8,159,854 \\
0.870 \\
2072 \\
\end{array}$ & $\begin{array}{c}37,977,219 \\
0.477 \\
3813 \\
\end{array}$ & $\begin{array}{c}15,463,288 \\
0.825 \\
2351 \\
\end{array}$ & $\begin{array}{c}5,316,284 \\
0.881 \\
1418 \\
\end{array}$ & $\begin{array}{c}8,349,204 \\
0.870 \\
2090 \\
\end{array}$ & $\begin{array}{c}39,451,814 \\
0.480 \\
3867 \\
\end{array}$ & $\begin{array}{c}15,827,482 \\
0.823 \\
2392 \\
\end{array}$ \\
\hline & \multicolumn{8}{|c|}{ Panel B: Individual-Specific Characteristics } \\
\hline & \multicolumn{4}{|c|}{ Salary } & \multicolumn{4}{|c|}{ Age } \\
\hline Dep. Var.: & $\log (\text { distance })_{i t}$ & $\log (\text { bus distance })_{i t}$ & formal $_{i t}$ & $\log (\text { salary })_{i t}$ & $\log (\text { distance })_{i t}$ & $\log (\text { bus distance })_{i t}$ & formal $_{i t}$ & $\log (\text { salary })_{i t}$ \\
\hline $\begin{array}{l}\operatorname{win}_{i t} \\
\operatorname{win}_{i t} * \log (\text { salary })_{i}\end{array}$ & $\begin{array}{c}1.3504^{* * * *} \\
{[0.1868]} \\
-0.1978^{* * *} \\
{[0.0292]}\end{array}$ & $\begin{array}{c}1.5214^{* * *} \\
{[0.1764]} \\
-0.2189^{* * *} \\
{[0.0278]}\end{array}$ & $\begin{array}{c}0.5987^{* * *} \\
{[0.0338]} \\
-0.0914^{* * *} \\
{[0.0054]}\end{array}$ & $\begin{array}{c}10.5931^{* * *} \\
{[0.2431]} \\
-1.6539^{* * *} \\
{[0.0393]}\end{array}$ & $\begin{array}{c}0.4181^{* * *} \\
{[0.0421]}\end{array}$ & $\begin{array}{c}0.3947^{* * *} \\
{[0.0402]}\end{array}$ & $\begin{array}{c}0.9680^{* * *} \\
{[0.0112]}\end{array}$ & $\begin{array}{c}1.9246^{* * *} \\
{[0.0351]}\end{array}$ \\
\hline $\operatorname{win}_{i t} * a g e_{i}$ & & & & & $\begin{array}{c}-0.0128^{* * *} \\
{[0.0011]}\end{array}$ & $\begin{array}{c}-0.0116^{* * *} \\
{[0.0010]}\end{array}$ & $\begin{array}{c}-0.0343^{* * *} \\
{[0.0004]}\end{array}$ & $\begin{array}{c}-0.0697^{* * *} \\
{[0.0013]}\end{array}$ \\
\hline $\begin{array}{l}\text { Observations } \\
R^{2} \\
\text { K-P F-Stat } \\
\end{array}$ & $\begin{array}{c}4,963,737 \\
0.874 \\
685 \\
\end{array}$ & $\begin{array}{c}7,612,978 \\
0.860 \\
1111 \\
\end{array}$ & $\begin{array}{c}38,173,800 \\
0.474 \\
3061 \\
\end{array}$ & $\begin{array}{l}17,393,949 \\
0.742 \\
2112 \\
\end{array}$ & $\begin{array}{c}5,875,858 \\
0.881 \\
1453 \\
\end{array}$ & $\begin{array}{c}9,188,521 \\
0.870 \\
2154 \\
\end{array}$ & $\begin{array}{c}44,910,600 \\
0.476 \\
4046 \\
\end{array}$ & $\begin{array}{c}17,393,716 \\
0.804 \\
2538 \\
\end{array}$ \\
\hline $\begin{array}{l}\text { Group-Year FE } \\
\text { Individual FE } \\
\text { Clustered SE } \\
\end{array}$ & $\begin{array}{l}\text { yes } \\
\text { yes } \\
\text { group }\end{array}$ & $\begin{array}{l}\text { yes } \\
\text { yes } \\
\text { group }\end{array}$ & $\begin{array}{l}\text { yes } \\
\text { yes } \\
\text { group }\end{array}$ & $\begin{array}{l}\text { yes } \\
\text { yes } \\
\text { group }\end{array}$ & $\begin{array}{l}\text { yes } \\
\text { yes } \\
\text { group }\end{array}$ & $\begin{array}{l}\text { yes } \\
\text { yes } \\
\text { group }\end{array}$ & $\begin{array}{l}\text { yes } \\
\text { yes } \\
\text { group }\end{array}$ & $\begin{array}{l}\text { yes } \\
\text { yes } \\
\text { group }\end{array}$ \\
\hline
\end{tabular}

This table depicts the results from the second stage estimation in equation $(3 \mathrm{~b})$ additionally interacting the independent variable with a measure of public transportation $n b$ bus lines $m$ (defined as the ratio of bus lines per square kilometer in a municipality) in Panel A, columns I to IV, a measure of local employment opportunities $n b$ firms $_{m}$ (defined as the number of firms per square kilometer in a municipality) in Panel A, columns V to VIII, the log of the pre-treatment salary of an individual in Panel B, columns I to IV, and the age of an individual in columns V to VIII. The dependent variable is the log distance between individual $i$ 's home and workplace in month $t$ in column I, the log distance between individual $i$ 's workplace and the nearest bus stop in column II, a dummy variable that takes the value of one if individual $i$ is formally employed in month $t$ and zero otherwise in column III, and the log of individual $i$ 's salary in month $t$ in column IV. The variable $w_{i n}$ it takes the value of one from the month an individual receives credit for motorcycle purchase and zero before. Standard errors are reported in parentheses. The bottom of the table provides information on fixed effects and the clustering of standard errors. $* * *$ and ${ }^{* *}$ denote statistical significance at the $1 \%$ and $5 \%$ levels, respectively. 


\section{Table 6: Dynamic Specification}

\begin{tabular}{|c|c|c|c|c|}
\hline & I & II & III & IV \\
\hline Dep. Var.: & $\log (\text { distance })_{i t}$ & $\log (\text { bus distance })_{i t}$ & formal $_{i t}$ & $\log (\text { salary })_{i t}$ \\
\hline$\overline{\beta_{i t}^{-5}}$ & $\begin{array}{l}-0.0092 \\
{[0.0537]}\end{array}$ & $\begin{array}{c}0.0572 \\
{[0.0535]}\end{array}$ & $\begin{array}{l}-0.0091 \\
{[0.0080]}\end{array}$ & $\begin{array}{c}0.0393 \\
{[0.0260]}\end{array}$ \\
\hline$\beta_{i t}^{-4}$ & $\begin{array}{l}-0.0017 \\
{[0.0410]}\end{array}$ & $\begin{array}{l}0.0306 \\
{[0.0404]}\end{array}$ & $\begin{array}{l}-0.0108 \\
{[0.0065]}\end{array}$ & $\begin{array}{c}0.0187 \\
{[0.0191]}\end{array}$ \\
\hline$\beta_{i t}^{-3}$ & {$[0.0298]$} & {$[0.0163$} & {$[0.0051]$} & $\begin{array}{c}0.0199 \\
{[0.0131]}\end{array}$ \\
\hline$\beta_{i t}^{-2}$ & $\begin{array}{c}0.0062 \\
{[0.0173]}\end{array}$ & $\begin{array}{c}0.0144 \\
{[0.0178]}\end{array}$ & $\begin{array}{l}-0.0016 \\
{[0.0034]}\end{array}$ & {$[0.0100$} \\
\hline$\beta_{i t}^{0}$ & $\begin{array}{c}0.0460 * * * \\
{[0.0156]}\end{array}$ & $\begin{array}{c}0.0334^{* *} \\
{[0.0158]}\end{array}$ & $\begin{array}{c}0.0184^{* * *} \\
{[0.0034]}\end{array}$ & $\begin{array}{c}0.0406 * * * \\
{[0.0063]}\end{array}$ \\
\hline$\beta_{i t}^{1}$ & $\begin{array}{c}0.0888^{* * *} \\
{[0.0235]}\end{array}$ & $\begin{array}{c}0.0945^{* * * *} \\
{[0.0241]}\end{array}$ & $\begin{array}{c}0.0200 * * * \\
{[0.0047]}\end{array}$ & $\begin{array}{c}0.0674^{* * * *} \\
{[0.0099]}\end{array}$ \\
\hline$\beta_{i t}^{2}$ & $\begin{array}{c}0.1161^{* * *} \\
{[0.0304]}\end{array}$ & $\begin{array}{c}0.1167^{* * *} \\
{[0.0304]}\end{array}$ & $\begin{array}{c}0.0160^{* * *} \\
{[0.0058]}\end{array}$ & $\begin{array}{c}0.0870^{* * *} \\
{[0.0123]}\end{array}$ \\
\hline$\beta_{i t}^{3}$ & $\begin{array}{c}0.1724 * * * \\
{[0.0390]}\end{array}$ & $\begin{array}{c}0.1365^{* * *} \\
{[0.0384]}\end{array}$ & $\begin{array}{c}0.0164 * * * \\
{[0.0072]}\end{array}$ & $\begin{array}{c}0.1013^{* * * *} \\
{[0.0154]}\end{array}$ \\
\hline$\beta_{i t}^{4}$ & $\begin{array}{c}0.1785^{* * *} \\
{[0.0373]}\end{array}$ & $\begin{array}{c}0.1325^{* * *} \\
{[0.0381]}\end{array}$ & $\begin{array}{c}0.0161^{* * *} \\
{[0.0072]}\end{array}$ & $\begin{array}{c}0.1057 * * * \\
{[0.0149]}\end{array}$ \\
\hline$\beta_{i t}^{5}$ & $\begin{array}{c}0.2184^{* * *} \\
{[0.0544]}\end{array}$ & $\begin{array}{c}0.1308^{* * *} * \\
{[0.0514]}\end{array}$ & $\begin{array}{c}0.0229 * * * \\
{[0.0102]}\end{array}$ & $\begin{array}{c}0.1791^{* * *} * \\
{[0.0224]}\end{array}$ \\
\hline $\begin{array}{l}\text { Group-Year FE } \\
\text { Individual FE } \\
\text { Clustered SE }\end{array}$ & $\begin{array}{l}\text { yes } \\
\text { yes } \\
\text { group }\end{array}$ & $\begin{array}{l}\text { yes } \\
\text { yes } \\
\text { group }\end{array}$ & $\begin{array}{l}\text { yes } \\
\text { yes } \\
\text { group }\end{array}$ & $\begin{array}{l}\text { yes } \\
\text { yes } \\
\text { group }\end{array}$ \\
\hline $\begin{array}{l}\text { Observations } \\
R^{2} \\
\text { K-P F-Stat } \\
\end{array}$ & $\begin{array}{c}5,875,877 \\
0.881 \\
92 \\
\end{array}$ & $\begin{array}{c}9,188,563 \\
0.870 \\
142 \\
\end{array}$ & $\begin{array}{c}44,912,112 \\
0.486 \\
716 \\
\end{array}$ & $\begin{array}{c}17,393,949 \\
0.823 \\
269 \\
\end{array}$ \\
\hline
\end{tabular}

This table depicts the results from the second stage estimation of equation (4b). The dependent variable is the $\log$ distance between individual $i$ 's home and workplace in month $t$ in column I, the $\log$ distance between individual $i$ 's workplace and the nearest bus stop in column II, a dummy variable that takes the value of one if individual $i$ is formally employed in month $t$ and zero otherwise in column III, and the $\log$ of individual $i$ 's salary in month $t$ in column IV. The independent variables indicate whether an individual has received credit for motorcycle purchase $t$ years earlier. Standard errors are reported in parentheses. The bottom of the table provides information on fixed effects and the clustering of standard errors. $* * *$ and $* *$ denote statistical significance at the $1 \%$ and $5 \%$ levels, respectively. 
Table 7: Timing of Access to Credit

\begin{tabular}{|c|c|c|c|c|}
\hline & I & II & III & IV \\
\hline Dep. Var.: & $\log \left(\right.$ distance $_{i}$ & $\log (\text { bus distance })_{i t}$ & formal $_{i t}$ & $\log (\operatorname{salary})_{i t}$ \\
\hline$\overline{\beta_{i t}^{-5} * \text { winyear }_{i}}$ & $\begin{array}{c}0.0007 \\
{[0.0034]}\end{array}$ & $\begin{array}{c}0.0009 \\
{[0.0032]}\end{array}$ & $\begin{array}{l}-0.0005 \\
{[0.0006]}\end{array}$ & $\begin{array}{c}0.0003 \\
{[0.0017]}\end{array}$ \\
\hline$\beta_{i t}^{-4} *$ winyear $_{i}$ & $\begin{array}{c}0.0013 \\
{[0.0031]}\end{array}$ & $\begin{array}{l}0.0025 \\
{[0.0032]}\end{array}$ & $\begin{array}{l}-0.0006 \\
{[0.0010]}\end{array}$ & $\begin{array}{l}-0.0014 \\
{[0.0013]}\end{array}$ \\
\hline$\beta_{i t}^{-3} *$ winyear $_{i}$ & $\begin{array}{c}0.0002 \\
{[0.0026]}\end{array}$ & $\begin{array}{c}0.0027 \\
{[0.0026]}\end{array}$ & $\begin{array}{l}-0.0004 \\
{[0.0009]}\end{array}$ & $\begin{array}{l}-0.0014 \\
{[0.0011]}\end{array}$ \\
\hline$\beta_{i t}^{-2} *$ winyear $_{i}$ & $\begin{array}{c}0.0005 \\
{[0.0018]}\end{array}$ & $\begin{array}{c}0.0001 \\
{[0.0019]}\end{array}$ & $\begin{array}{l}-0.0005 \\
{[0.0006]}\end{array}$ & $\begin{array}{l}-0.0003 \\
{[0.0007]}\end{array}$ \\
\hline$\beta_{i t}^{0} *$ winyear $_{i}$ & $\begin{array}{l}-0.0001 \\
{[0.0017]}\end{array}$ & $\begin{array}{l}-0.0008 \\
{[0.0017]}\end{array}$ & {$[0.0001$} & $\begin{array}{l}0.0012^{* *} \\
{[0.0006]}\end{array}$ \\
\hline$\beta_{i t}^{1} *$ winyear $_{i}$ & $\begin{array}{l}-0.0016 \\
{[0.0023]}\end{array}$ & $\begin{array}{c}0.0004 \\
{[0.0023]}\end{array}$ & {$[0.00011]$} & $\begin{array}{l}0.0015^{*} \\
{[0.0008]}\end{array}$ \\
\hline$\beta_{i t}^{2} *$ winyear $_{i}$ & $\begin{array}{l}-0.0048^{*} \\
{[0.0028]}\end{array}$ & $\begin{array}{l}0.0006 \\
{[0.0028]}\end{array}$ & $\begin{array}{l}0.0005 \\
{[0.0018]}\end{array}$ & $\begin{array}{l}0.0021^{*} \\
{[0.0011]}\end{array}$ \\
\hline$\beta_{i t}^{3} *$ winyear $_{i}$ & $\begin{array}{l}-0.0018 \\
{[0.0035]}\end{array}$ & $\begin{array}{l}-0.0011 \\
{[0.0036]}\end{array}$ & $\begin{array}{c}0.0003 \\
{[0.0036]}\end{array}$ & $\begin{array}{c}0.0031^{* *} \\
{[0.0015]}\end{array}$ \\
\hline$\beta_{i t}^{4} *$ winyear $_{i}$ & $\begin{array}{c}0.0009 \\
{[0.0032]}\end{array}$ & $\begin{array}{l}0.0006 \\
{[0.0032]}\end{array}$ & $\begin{array}{c}0.0006 \\
{[0.0051]}\end{array}$ & $\begin{array}{l}0.0027^{* *} \\
{[0.0013]}\end{array}$ \\
\hline$\beta_{i t}^{5} *$ winyear $_{i}$ & $\begin{array}{l}-0.0035 \\
{[0.0022]}\end{array}$ & $\begin{array}{c}0.0000 \\
{[0.0023]}\end{array}$ & $\begin{array}{c}-0.0012^{* *} \\
{[0.0046]}\end{array}$ & $\begin{array}{c}-0.0056^{* * *} \\
{[0.0010]}\end{array}$ \\
\hline $\begin{array}{l}\text { Group-Year FE } \\
\text { Individual FE } \\
\text { Clustered SE }\end{array}$ & $\begin{array}{l}\text { yes } \\
\text { yes } \\
\text { group }\end{array}$ & $\begin{array}{l}\text { yes } \\
\text { yes } \\
\text { group }\end{array}$ & $\begin{array}{l}\text { yes } \\
\text { yes } \\
\text { group }\end{array}$ & $\begin{array}{l}\text { yes } \\
\text { yes } \\
\text { group }\end{array}$ \\
\hline $\begin{array}{l}\text { Observations } \\
R^{2} \\
\text { K-P F-Stat } \\
\end{array}$ & $\begin{array}{c}5,875,877 \\
0.881 \\
13 \\
\end{array}$ & $\begin{array}{c}9,188,563 \\
0.870 \\
23 \\
\end{array}$ & $\begin{array}{c}44,912,112 \\
0.486 \\
48\end{array}$ & $\begin{array}{c}17,393,949 \\
0.824 \\
23 \\
\end{array}$ \\
\hline
\end{tabular}

This table depicts the results from the second stage estimation in equation (4b). The dependent variable is the $\log$ distance between individual $i$ 's home and workplace in month $t$ in column I, the $\log$ distance between individual $i$ 's workplace and the nearest bus stop in column II, a dummy variable that takes the value of one if individual $i$ is formally employed in month $t$ and zero otherwise in column III, and the $\log$ of individual $i$ 's salary in month $t$ in column IV. The independent variables indicate whether an individual has received credit for motorcycle purchase $t$ years earlier. The variable winyear $_{i}$ takes the value of one if an individual obtains credit in the first year of a consorcio group, two if an individual obtains credit in the second year, and so on. While we do not separately report the estimates for $\beta_{i t}$, they are included in the regression. Standard errors are reported in parentheses. The bottom of the table provides information on fixed effects and the clustering of standard errors. ${ }^{* *}, * *$, and $*$ denote statistical significance at the $1 \%, 5 \%$, and $10 \%$ levels, respectively. 
Table 8: Inputs for Value of Access to Credit

\begin{tabular}{|c|c|c|}
\hline Variable & Source & Value \\
\hline$\overline{\mathbb{E}\left[\log \left(S_{0}^{M}\right)-\log \left(S_{0}^{B}\right)\right]}$ & Table6, column IV, line 5 & 0.0406 \\
\hline $\mathbb{E}\left[\log \left(S_{1}^{M}\right)-\log \left(S_{1}^{B}\right)\right]$ & Table6, column IV, line 6 & 0.0674 \\
\hline $\mathbb{E}\left[\log \left(S_{2}^{M}\right)-\log \left(S_{2}^{B}\right)\right]$ & Table6, column IV, line 7 & 0.0870 \\
\hline $\mathbb{E}\left[\log \left(S_{3}^{M}\right)-\log \left(S_{3}^{B}\right)\right]$ & Table6, column IV, line 8 & 0.1013 \\
\hline $\mathbb{E}\left[\log \left(S_{4}^{M}\right)-\log \left(S_{4}^{B}\right)\right]$ & Table6, column IV, line 9 & 0.1057 \\
\hline $\mathbb{E}\left[\log \left(S_{5}^{M}\right)-\log \left(S_{5}^{B}\right)\right]$ & Table6, column IV, line 10 & 0.1791 \\
\hline $\mathbb{E}\left[\log \left(S_{6}^{M}\right)-\log \left(S_{6}^{B}\right)\right]$ & Table6, column IV, line 10 & 0.1791 \\
\hline $\mathbb{E}\left[\log \left(S_{7}^{M}\right)-\log \left(S_{7}^{B}\right)\right]$ & Table6, column IV, line 10 & 0.1791 \\
\hline $\mathbb{E}\left[\log \left(S_{8}^{M}\right)-\log \left(S_{8}^{B}\right)\right]$ & Table6, column IV, line 10 & 0.1791 \\
\hline $\mathbb{E}\left[\log \left(S_{9}^{M}\right)-\log \left(S_{9}^{B}\right)\right]$ & Table6, column IV, line 10 & 0.1791 \\
\hline $\mathbb{E}\left[\log \left(S_{10}^{M}\right)-\log \left(S_{10}^{B}\right)\right]$ & Table6, column IV, line 10 & 0.1791 \\
\hline$M$ & Administrative data & 48 \\
\hline$x_{0}$ & Administrative data & 0.2325 \\
\hline$x_{1}$ & Administrative data & 0.2903 \\
\hline$x_{2}$ & Administrative data & 0.3277 \\
\hline$x_{3}$ & Administrative data & 0.3397 \\
\hline$x_{4}$ & Administrative data & 0.3440 \\
\hline$x_{5}$ & Administrative data & 0.3456 \\
\hline
\end{tabular}

This table lists the estimates for the variables required to compute the value of access to credit for investment in individual mobility that are described in the text and lists their sources. The estimate from Table6, column IV, line 10 corresponds to the average effect from five to ten years after obtaining credit. 
Table 9: Robustness Tests - Measurement

\begin{tabular}{|c|c|c|c|}
\hline & I & II & III \\
\hline Dep. Var.: & $\log ($ distance $)$ & $\log (\text { bus distance })_{i t}$ & $\log (\operatorname{salar} y)_{i t}$ \\
\hline $\operatorname{win}_{i t}$ & $\begin{array}{c}0.0447^{* *} \\
{[0.0201]}\end{array}$ & $\begin{array}{c}0.0599 * * * \\
{[0.0209]} \\
\end{array}$ & $\begin{array}{c}0.0363^{* * *} \\
{[0.0127]} \\
\end{array}$ \\
\hline $\begin{array}{l}\text { Group-Year FE } \\
\text { Individual FE } \\
\text { Clustered SE }\end{array}$ & $\begin{array}{l}\text { yes } \\
\text { yes } \\
\text { group }\end{array}$ & $\begin{array}{l}\text { yes } \\
\text { yes } \\
\text { group }\end{array}$ & $\begin{array}{l}\text { yes } \\
\text { yes } \\
\text { group }\end{array}$ \\
\hline $\begin{array}{l}\text { Observations } \\
R^{2} \\
\text { K-P F-Stat }\end{array}$ & $\begin{array}{l}5,864,455 \\
0.882 \\
2971 \\
\end{array}$ & $\begin{array}{c}9,147,337 \\
0.871 \\
4415\end{array}$ & $\begin{array}{c}8,830,329 \\
0.857 \\
3501 \\
\end{array}$ \\
\hline
\end{tabular}

This table depicts the results of robustness tests based on the second stage estimation in equation (3b). The dependent variable is the log distance between individual $i$ 's home and workplace in month $t$ in column I, the log distance between individual $i$ 's workplace and the nearest bus stop in month $t$ in column II, and the log of individual $i$ 's salary in month $t$ in column III. In columns I and II, the sample is restricted to individuals living in municipalities with at least 50,000 inhabitants. In column III, the sample is restricted to municipalities with above median levels of labor market formality. The variable $w_{i n}$ it takes the value of one from the month an individual receives credit for motorcycle purchase and zero before. Standard errors are reported in parentheses. The bottom of the table provides information on fixed effects and the clustering of standard errors. ${ }^{* * *}$ and $* *$ denote statistical significance at the $1 \%$ and $5 \%$ levels, respectively.

Table 10: Anticipation of Lottery Win

\begin{tabular}{|c|c|c|c|c|}
\hline & I & II & III & IV \\
\hline Dep. Var.: & $\log (\text { distance })_{i t}$ & $\log (\text { bus distance })_{i t}$ & formal $_{i t}$ & $\log (\text { salary })_{i t}$ \\
\hline$P[w i n]_{i t}$ & $\begin{array}{c}0.0015 \\
{[0.0013]}\end{array}$ & $\begin{array}{l}-0.0024 \\
{[0.0021]}\end{array}$ & $\begin{array}{c}0.0005 \\
{[0.0004]}\end{array}$ & $\begin{array}{c}0.0002 \\
{[0.0004]}\end{array}$ \\
\hline $\begin{array}{l}\text { Group-Year FE } \\
\text { Individual FE } \\
\text { Clustered SE }\end{array}$ & $\begin{array}{c}\text { yes } \\
\text { yes } \\
\text { group }\end{array}$ & $\begin{array}{c}\text { yes } \\
\text { yes } \\
\text { group }\end{array}$ & $\begin{array}{c}\text { yes } \\
\text { yes } \\
\text { group }\end{array}$ & $\begin{array}{c}\text { yes } \\
\text { yes } \\
\text { group }\end{array}$ \\
\hline $\begin{array}{l}\text { Observations } \\
R^{2}\end{array}$ & $\begin{array}{c}5,045,420 \\
0.884 \\
\end{array}$ & $\begin{array}{c}7,756,795 \\
0.872 \\
\end{array}$ & $\begin{array}{c}38,916,115 \\
0.504\end{array}$ & $\begin{array}{c}15,066,572 \\
0.830\end{array}$ \\
\hline
\end{tabular}

In this table, the dependent variable is the log distance between individual $i$ 's home and workplace in month $t$ in column $\mathrm{I}$, the $\log$ distance between individual $i$ 's workplace and the nearest bus stop in column II, a dummy variable that takes the value of one if individual $i$ is formally employed in month $t$ and zero otherwise in column III, and the $\log$ of individual $i$ 's salary in month $t$ in column IV. The variable $P[\text { win }]_{i t}$ is the probability that individual $i$ wins a credit lottery in month $t+1$. Standard errors are reported in parentheses. The bottom of the table provides information on fixed effects and the clustering of standard errors. 


\section{Appendix A. Credit Allocation in Consorcio Groups}

In this section, we provide an example of an algorithm to illustrate the credit allocation procedure in consorcio groups and the implementation of our instrument variable (IV) strategy.

\section{Appendix A.1. Algorithm: Example}

Each week, five five-digit numbers are drawn in Brazil's national lottery. While there are a large number of different algorithm used by different administrators, they all share the key feature that each participant has the same unconditional probability of winning the lottery in every allocation period.

The algorithm that we use for the example in this section uses the first of the five-digit numbers from the national lottery to determine the allocation of credit. The number is divided by the number of participants in the group and then takes the remainder is multiplies by the number of participants. For example, if the number from the national lottery is 10084 and there are 250 participants in the group, the remainder from dividing 10084 by 250 is 0.336 , which multiplied by 250 is 84 . Thus, credit would be allocated to the participant with ticket number $84 .^{17}$

If the individual with ticket number 84 has already been awarded credit in a previous round, the algorithm simply adds one to the initial result. In our example, this means that credit would be allocated to the holder of ticket number 85 . If this participant has also been awarded credit before, the algorithm subtracts one from the initial result, which in our case would imply that ticket number 83 is awarded credit. The algorithm continues to add and subtract two, then three, and so on, relative to the initial result, until a ticket number is selected that has not been awarded credit before.

\section{Appendix A.2. Simulated Allocation}

The majority of consorcio groups combine credit allocation through lotteries and auctions. The allocation of credit through auctions is a threat to our empirical analysis since, unlike for lotteries, the outcome of auctions is not random and is potentially endogenous with respect to labor market outcomes. For example, individuals with better labor market opportunities are more likely to submit higher bids

\footnotetext{
${ }^{17}$ If the remainder is zero, credit goes to the highest ticket number.
} 
and therefore obtain credit for motorcycle purchase earlier. This source of endogeneity is not eliminated by limiting attention to lottery winners. Over time, individuals who obtain credit through auctions disappear from the pool of potential lottery winners. If auction winners systematically differ on important characteristics, such as better labor market opportunities, the control group of non-winners is depleted of individuals with better labor market opportunities over time. This could lead to a bias in estimating the effect of obtaining credit for motorcycle purchase on labor market outcomes.

As a consequence, we resort to an instrumental variable strategy that simulates the allocation of credit in each consorcio group as if all credit is allocated through lotteries. To do so, we combine data on the outcome of the national lottery with data on the ticket numbers of all consorcio group participants and the algorithm used by a given group. This procedure allows us to simulate the allocation of credit within groups, as if only lotteries but no auctions were held. We restrict our analysis to groups for which we have information on the algorithm that they use.

Next, we illustrate this procedure using a fictional example. Suppose that a group has 200 members and allocates credit to two members every period, one through a lottery and one through an auction. Suppose that in the first period the lottery winner is ticket number 25 and the auction winner is ticket number 60 . In the next period, the lottery is won by ticket number 30 and the auction is won by ticket number 80 . In the third period, the algorithm determines ticket number 60 as the winner of the lottery. However, since ticket number 60 obtained credit through the auction in the first period, the ultimate lottery winner in the real group is ticket 61 . Hence, the presence of auctions has altered the order in which credit is allocated compared to an allocation based purely on lotteries. Instead, in the simulated group, the lottery winner would be ticket number 60 , as the outcomes of auctions are ignored.

Thus, for the first three periods our instrument from the simulated lotteries would predict the lottery winners to be ticket numbers 25,30 , and 60 , since these are the numbers that would have won the lottery if the group did not hold auctions. We simulate all lotteries for each group from the first to the last period and predict lottery winners through this procedure, which avoids distortions in the timing of lottery winners due to the presence of auctions. 